Cite this: New J. Chem. 2016 40, 5364

Received (in Montpellier, France) 9th December 2015,

Accepted 6th April 2016

DOI: $10.1039 / c 5 n j 03502 c$

www.rsc.org/njc

\section{Sparingly fluorinated maltoside-based surfactants for membrane-protein stabilization $\dagger$}

\author{
Ange Polidori, ${ }^{a}$ Simon Raynal, ${ }^{a}$ Laurie-Anne Barret, ${ }^{a b}$ Mohamed Dahani, ${ }^{a}$ \\ Cherone Barrot-Ivolot, ${ }^{a}$ Colette Jungas, ${ }^{b}$ Erik Frotscher, ${ }^{C}$ Sandro Keller, ${ }^{c}$ \\ Christine Ebel, ${ }^{\text {def }}$ Cécile Breyton ${ }^{\text {def }}$ and Françoise Bonneté ${ }^{* a}$
}

\begin{abstract}
Membrane proteins pose formidable challenges during in vitro investigations, as they require amphiphilic molecules for their solubilization, stabilization, and crystallization for structural characterization. Therefore, numerous, chemically diverse new amphiphiles have been developed for membrane-protein applications. Among these, both perfluorinated and hemifluorinated surfactants have long been known to stabilize membrane proteins, but the contribution of the fluorine content in the aliphatic chain has not yet been examined in detail. We have synthesized two new maltose-based fluorosurfactants bearing either a perfluoroethyl $\left(\mathrm{F}_{2} \mathrm{H}_{9}\right)$ or a perfluorobutyl $\left(\mathrm{F}_{4} \mathrm{H}_{5}\right)$ tip at the end of the chain and compared them with the common detergent dodecyl maltoside and a commercial highly fluorinated octyl maltoside derivative. We describe the physicochemical properties, aggregate morphologies, and micellization thermodynamics of these sparingly fluorinated surfactants as a function of the length of the fluorinated segment and evaluate their biochemical use for membrane-protein stabilization. Intriguingly, the surfactant carrying a perfluorobutyl $\left(\mathrm{F}_{4} \mathrm{H}_{5}\right)$ tip trumps both nonfluorinated dodecyl maltoside and a more extensively fluorinated octyl maltoside derivative in conferring extraordinary long-term functional and colloidal stability to the model membrane protein bacteriorhodopsin.
\end{abstract}

\section{Introduction}

Membrane proteins (MPs) play key roles in signal and mass transfer across lipid bilayers, which form dynamic interfaces between cellular compartments or between a cell and its environment. Although the genes encoding MPs represent on average $30 \%$ of genomes and the corresponding proteins $60 \%$ of all therapeutic targets, ${ }^{1}$ there is a lack of structural information compared with that available for soluble proteins. During the last four decades, the characterization of MPs has been a major challenge in structural biology, one of the main bottlenecks consisting in finding detergents suitable for their extraction and

\footnotetext{
${ }^{a}$ Institut des Biomolécules Max Mousseron (IBMM) UMR 5247 CNRS-UM-ENSCM, Chimie BioOrganique et Systèmes Amphiphiles, Université d'Avignon, 301, rue Baruch de Spinoza, F84000 Avignon, France. E-mail: francoise.bonnete@univ-avignon.fr

${ }^{b}$ Laboratoire de Génétique et de Biophysique des Plantes (L.G.B.P) UMR 7265 CNRS-CEA-AMU, Faculté des Sciences de Luminy, 163 avenue de Luminy, F-13009 Marseille, France

${ }^{c}$ Molecular Biophysics, University of Kaiserslautern, Erwin-Schrödinger-Str. 13, 67663 Kaiserslautern, Germany

${ }^{d}$ Université Grenoble Alpes, IBS, F-38044 Grenoble, France

${ }^{e}$ CNRS, IBS, F-38044 Grenoble, France

${ }^{f}$ CEA, IBS, F-38044 Grenoble, France

$\dagger$ Electronic supplementary information (ESI) is available: Additional characterization. See DOI: 10.1039/c5nj03502c
}

handling in a native and active state. The stability of proteindetergent complexes (PDCs) depends both on the type and on the concentration of the detergent. Detergent concentrations below the critical micellar concentration (CMC) can cause MPs to aggregate and precipitate; conversely, high detergent concentrations may inactivate them. The amount of detergent molecules bound to transmembrane regions is highly variable and can be very large, thus modifying considerably the size and the mass of PDCs. For example, Bamber et al. have shown that, as the length of the aliphatic chain in $n$-alkyl- $\beta$-D-maltosides decreases, PDCs become smaller and thus expose more MP surface area. ${ }^{2}$

It is thus clear that detergent packing around MPs will significantly contribute to understand how complexes interact and self-assemble during phase transition and crystallization and how PDCs pack into the crystal. ${ }^{3,4}$ For example, detergents forming large micelles, such as $n$-dodecyl- $\beta$-D-maltoside $\left(\mathbf{H}_{\mathbf{1 2}} \boldsymbol{\beta} \mathbf{M}\right)$ and polyoxyethylene dodecyl ether $\left(\mathrm{C}_{12} \mathrm{E}_{9}\right)$, are more likely to keep a MP in solution by efficiently shielding its apolar surface; however, the large size of the micelle means that less protein surface is available to form protein-protein interactions essential for crystal-lattice formation. ${ }^{5}$ By contrast, small-micelle detergents, such as $n$-octyl- $\beta$-D-glucoside $(\beta O G)$ and $n$-octyl- $\beta$-D-maltoside $(\beta \mathrm{OM})$, leave more of the protein exposed to form proteinprotein interactions necessary for strong crystal contacts but 
may also inactivate MPs by the intrusion of the detergent alkyl chain into the interior of the protein or by stripping away stabilizing lipids, cofactors, or subunits. At this stage, one might wonder if a detergent suitable for stabilization is also good for crystallization.

Different strategies have been developed over two decades to synthesize new surfactants that allow in vitro synthesis, ${ }^{6,7}$ solubilization and purification, ${ }^{8,9}$ or trapping and stabilization ${ }^{10}$ of MPs. Most surfactants developed to date have been valuable for solubilizing and stabilizing MPs, but the number of surfactants amenable to crystallization and X-ray crystallography is rather limited. It seems reasonable that a hydrophobic chain that is less lipophilic towards residual lipids and cofactors and less intrusive towards transmembrane regions of the protein should be more stabilizing and thus more favorable for crystallization. Furthermore, new powerful amphiphiles for crystallization would cover less protein surface to favor protein-protein contacts in crystals while keeping MPs stable. This could be achieved by tighter control of the micellar assembly and the surfactant interactions with MPs.

Recently, we have characterized the physicochemical and structural properties of a new polycyclic maltoside surfactant, propyl(bi)cyclohexyl- $\alpha$-maltoside (PCC $\alpha \mathrm{M}) \cdot{ }^{11}$ The stability of the cytochrome $b_{6} f$ complex was higher in PCC $\alpha \mathbf{M}$ than in $\mathbf{H}_{\mathbf{1 2}} \boldsymbol{\beta} \mathbf{M}$, rendering PCC $\alpha \mathrm{M}$ suitable for crystallization. We further showed by small-angle X-ray scattering (SAXS) that micelles of $\mathbf{H}_{\mathbf{1 2}} \boldsymbol{\beta} \mathbf{M}$ and PCC $\alpha \mathrm{M}$ possess similar ellipsoidal sizes and shapes. However, aggregation numbers obtained from molar masses revealed that PCC $\alpha \mathrm{M}$ micelles $\left(N_{\mathrm{agg}} \approx 165\right)$ contain more surfactant monomers than $\mathbf{H}_{\mathbf{1 2}} \mathbf{\beta} \mathbf{M}$ micelles $\left(N_{\text {agg }} \approx 125\right) .{ }^{12}$ Moreover, second virial coefficients determined by SAXS revealed that intermicellar interactions are more attractive for PCC $\alpha \mathbf{M}$ than $\mathbf{H}_{\mathbf{1 2}} \mathbf{\beta} \mathbf{M}$, thus highlighting that the hydrophobic chain can greatly impact this kind of interaction. This resulted in a lower cloud point boundary for $\mathrm{PCC} \alpha \mathbf{M}$ than for $\mathbf{H}_{\mathbf{1 2}} \boldsymbol{\beta} \mathbf{M}$, which favored the crystallization of the MP target RC-LH1-pufX in this new surfactant; however, diffraction quality was not sufficiently improved to allow structure determination. In order to increase X-ray diffraction by a better packing of MP-surfactant complexes in crystals, new surfactants need to be designed with a degree of hydrophobicity that stabilizes MPs in a native and active form and, at the same time, promotes suitable attraction for crystallization.

Several series of fluorinated surfactants have been synthesized over the past 20 years and tested for handling MPs in aqueous solutions. ${ }^{13-18}$ These surfactants have the same general structure as classical detergents (i.e. a hydrophilic headgroup and a hydrophobic tail), but their hydrophobic tail is fully or partially fluorinated (e.g. $\mathrm{F}_{6}, \mathrm{~F}_{8}$ ). Since fluoroalkanes are both hydrophobic and poorly miscible with alkanes (i.e. lipophobic), ${ }^{19}$ this renders perfluorinated surfactants poor solvents for lipids and hydrophobic cofactors, although exceptions have recently been reported. ${ }^{20}$ As a result, most fluorinated surfactants are unable to efficiently extract MPs from native membranes. Furthermore, fluorinated surfactants present bulkier and more rigid hydrophobic chains than their hydrogenated counterparts and,

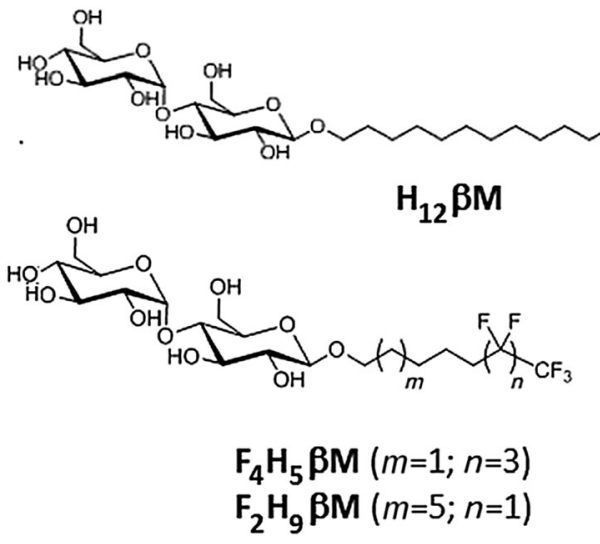

Scheme 1 Chemical structures of surfactants: $\mathrm{H}_{12} \beta M, \mathrm{~F}_{2} \mathrm{H}_{9} \beta M$ and $\mathrm{F}_{4} \mathrm{H}_{5} \beta \mathbf{M}$.

thus, are less likely to intrude into the protein structure itself, which makes them less denaturing for MPs. While the stabilization of MPs has been demonstrated in fluorinated surfactants (reviewed in ref. 21), no successful in surfo crystallization has yet been reported. For the crystallization of MPs in surfo, crucial parameters include the micelle morphology and the belt size around the protein to allow polar contacts in the crystal. Previous results obtained with fluorinated and hemifluorinated derivatives of $\mathbf{H}_{\mathbf{1 2}} \boldsymbol{\beta M}^{22}$ have shown that the structural heterogeneity observed with the $(\mathrm{H}) \mathrm{F}_{6}$-maltoside series was because the fluorinated alkyl chain being bulkier than the hydrogenated one. The length and the volume of the $\mathrm{F}_{6}$ segment influence the packing parameter ${ }^{23}$ of fluorinated surfactants and, therefore, the morphology of their aggregates formed in water. In order to form small globular micelles with maltose-based fluorinated surfactants, we have developed new fluorinated surfactants with a perfluoroethyl $\left(\mathrm{F}_{2} \mathrm{H}_{9}\right)$ or a perfluorobutyl $\left(\mathrm{F}_{4} \mathrm{H}_{5}\right)$ tip at the end of the aliphatic chain, whose overall hydrophilic/lipophobic balance is expected to be equivalent to that of $\mathbf{H}_{\mathbf{1 2}} \boldsymbol{\beta} \mathbf{M}$ (Scheme 1).

In this paper, we describe the synthesis of these two new sparingly fluorinated surfactants. We compare their physicochemical and micellar properties with those of commercial $n$-dodecyl- $\beta$-D-maltoside $\left(\mathbf{H}_{\mathbf{1 2}} \mathbf{\beta M}\right)$ and fluorinated octyl maltoside $\left(\mathrm{F}_{6} \mathrm{H}_{2} \beta \mathrm{M}\right)$ and perform a biochemical evaluation of MP complex stability and homogeneity using bacteriorhodopsin (bR) from the purple membrane as a model MP.

\section{Experimental section}

\section{Materials}

All starting materials were commercially available and used without further purification. All solvents were of reagent grade and used as received unless noted otherwise. THF and $\mathrm{MeOH}$ were dried over $\mathrm{Na}$, and $\mathrm{CH}_{2} \mathrm{Cl}_{2}$ was dried over $\mathrm{CaH}_{2}$ under an argon atmosphere. Commercially available anhydrous DMF was stored over activated molecular sieves $(3 \AA)$. The progress of reactions was monitored by thin-layer chromatography (TLC, Merck 254, silica plates), and compounds were detected either by exposure to ultraviolet light ( $254 \mathrm{~nm}$ ), iodine, or by spraying with a $0.05 \%$ sulfuric acid solution in ethanol followed by 
heating to $150{ }^{\circ} \mathrm{C}$. Flash chromatography purifications were carried out on silica gel (40-63 mm granulometry). Size exclusion chromatography purifications were carried out on Sephadex LH-20 resin. ${ }^{1} \mathrm{H}$ and ${ }^{13} \mathrm{C}$ NMR spectra were recorded on a Bruker Ascend 9.4-T spectrometer at $400 \mathrm{MHz}$ for ${ }^{1} \mathrm{H}, 376 \mathrm{MHz}$ for ${ }^{19} \mathrm{~F}$, and $100 \mathrm{MHz}$ for ${ }^{13} \mathrm{C}$. Chemical shifts ( $\delta$ values) are reported in ppm downfield from the internal residual solvent as a heteronuclear reference. High-resolution mass spectrometry by electrospray ionization (HRMS-ESI) was carried out on a QStar Elite mass spectrometer. Peracetylated $\beta$-maltoside was prepared according to the study of Vill et al. ${ }^{24}$

\section{Synthesis}

6,6,7,7,8,8,9,9,9-Nonafluorononan-1-ol (compound 1). A solution of 4-pentenol (1.02 g, $11 \mathrm{mmol})$ and perfluorobutyl iodide $(5.29 \mathrm{~g}, 15 \mathrm{mmol})$ in anhydrous dichloromethane $(10 \mathrm{~mL})$ was placed in a $25 \mathrm{~mL}$ round-bottomed flask under argon. Activated zinc ( $4 \mathrm{~g}, 61 \mathrm{mmol}$ ) was added and the mixture was stirred at ambient temperature for $4 \mathrm{~h}$ until the disappearance of vinyl protons was observed using ${ }^{1} \mathrm{H}$ NMR. The iodide obtained is visible in UV (TLC monitoring, cyclohexane : ethyl acetate $6: 4$ ). A mixture of water/acetic acid/12 $\mathrm{N} \mathrm{HCl} \mathrm{(30/15/5:} \mathrm{v/v/v)} \mathrm{was}$ added which dissolved zinc. The mixture was filtered through a pad of celite and washed with saturated $\mathrm{NaHCO}_{3}$ solution $(25 \mathrm{~mL})$. After drying over anhydrous sodium sulfate and the evaporation of the solvent, the residue was purified by column chromatography on silica gel (cyclohexane/ethyl acetate: $6: 4$ ) to give $2.2 \mathrm{~g}$ of liquid 1 (70\%).

${ }^{1} \mathrm{H}$ NMR $\delta\left(\mathrm{CDCl}_{3}\right): 1.45-1.51\left(\mathrm{~m}, \mathrm{CH}_{2}-\mathrm{CH}_{2}-\mathrm{CH}_{2}-, 2 \mathrm{H}\right)$, 1.58-1.68 (m, $\left.\mathrm{CF}_{2}-\mathrm{CH}_{2}-\mathrm{CH}_{2}-, \mathrm{CH}_{2}-\mathrm{CH}_{2}-\mathrm{OH}, 4 \mathrm{H}\right), 2.07$ (m, 2H, $\left.\mathrm{CH}_{2}-\mathrm{CF}_{2}, 2 \mathrm{H}\right), 3.67$ (t, $\left.\mathrm{CH}_{2} \mathrm{OH}, 2 \mathrm{H}\right) .{ }^{19} \mathrm{~F} \mathrm{NMR} \delta\left(\mathrm{CDCl}_{3}\right):-126.08$ $\left(\mathrm{t}, 2 \mathrm{~F}, \mathrm{CF}_{2}-\mathrm{CF}_{2}-\mathrm{CF}_{2}-\mathrm{CF}_{3}\right),-124.52\left(\mathrm{t}, 2 \mathrm{~F}, \mathrm{CF}_{2}-\mathrm{CF}_{2}-\mathrm{CF}_{2}-\mathrm{CF}_{3}\right)$, $-114.63\left(\mathrm{t}, 2 \mathrm{~F}, \mathrm{CH}_{2}-\mathrm{CF}_{2}-\mathrm{CF}_{2}-\mathrm{CF}_{2}-\mathrm{CF}_{3}\right),-81.06\left(\mathrm{~s}, 3 \mathrm{~F},-\mathrm{CF}_{3}\right)$. ${ }^{13} \mathrm{C} \quad \mathrm{NMR} \delta\left(\mathrm{CDCl}_{3}\right): 19.96,19.99\left(\mathrm{CF}_{2}-\mathrm{CH}_{2}-\mathrm{CH}_{2}-\right), 25.33$ $\left(\mathrm{CH}_{2}-\mathrm{CH}_{2}-\mathrm{CH}_{2}-\right), 30.75$ (t, $\left.\mathrm{CH}_{2}-\mathrm{CF}_{2}\right), 32.24\left(\mathrm{CH}_{2}-\mathrm{CH}_{2}-\mathrm{OH}\right)$, $62.48\left(\mathrm{CH}_{2} \mathrm{OH}\right)$.

$6^{\prime}, 6^{\prime}, 7^{\prime}, 7^{\prime}, 8^{\prime}, 8^{\prime}, 9^{\prime}, 9^{\prime}, 9^{\prime}$-Nonafluorononanyl tri-O-acetyl-4-O$(2,3,4,6$-tetra- $O$-acetyl- $\alpha$-D-glucopyranosyl)- $\beta$-D-glucopyranoside (compound 2). A solution of peracetylated maltose $(3.43 \mathrm{~g}$, $5 \mathrm{mmol}$ ) and compound 1 (1.55 g, $5 \mathrm{mmol})$ in anhydrous dichloromethane $(10 \mathrm{~mL})$ was placed in a $25 \mathrm{~mL}$ roundbottomed flask under argon. $\mathrm{BF}_{3}-\mathrm{Et}_{2} \mathrm{O}(0.8 \mathrm{~mL}, 3.14 \mathrm{mmol})$ was added at $0{ }^{\circ} \mathrm{C}$. The reaction was stirred at room temperature for $24 \mathrm{~h}$. Acetic anhydride was added $(1 \mathrm{~mL})$. The mixture was stirred for $2 \mathrm{~h}$. Triethylamine was added and the reaction mixture was diluted with dichloromethane $(50 \mathrm{~mL})$ and washed with water $(25 \mathrm{~mL}, 3$ times) and brine $(25 \mathrm{~mL})$. The organic layer was dried over anhydrous sodium sulfate and evaporated to dryness. The crude product was purified by column chromatography on silica gel (cyclohexane/EtOAc: $1 / 1$ ) to give $32 \%$ of the anomeric mixture of compound 2 in a $\alpha / \beta$ ratio of $5 / 95$ as an amorphous white powder. The mixture was recrystallized in hot methanol to give the pure $\beta$-anomer as a white powder.

${ }^{1} \mathrm{H}-\mathrm{NMR} \delta\left(\mathrm{CDCl}_{3}\right): 1.3-1.65\left(\mathrm{~m}, 8 \mathrm{H}, \mathrm{CH}_{2}-\left(\mathrm{CH}_{2}\right)_{3}-\mathrm{CH}_{2}-\mathrm{CF}_{2}-\right)$, 2.0-2.14 (m, 23H, acetyl groups, $\left.\mathrm{CH}_{2}-\mathrm{CF}_{2}\right), 3.5$ (m, $\left.1 \mathrm{H}, \mathrm{O}-\mathrm{CH}_{2}\right)$,
3.65 (m, 1H, H5), 3.87 (m, 1H, O- $\mathrm{CH}_{2}$ ), 3.9-4.1 (m, 3H, H4, H5', H6'a), 4.15-4.35 (m, 2H, H6b, H6 'b), 4.45 (d, 1H, H6a), 4.5-4.55 (d, $\left.1 \mathrm{H}, \mathrm{H} 1,{ }^{3} J_{1,2}=7.5 \mathrm{~Hz}\right), 4.75-4.95\left(\mathrm{~m}, 2 \mathrm{H}, \mathrm{H} 2, \mathrm{H} 2^{\prime}\right), 5-5.15$ (d, 1H, H4 $4^{\prime}$ ), 5.25 (t, 1H, H3), 5.36 (t, 1H, H3 $\left.{ }^{\prime}\right), 5.42$ (d, 1H, H1 ${ }^{\prime}$, $\left.{ }^{3} J_{1,2}=4 \mathrm{~Hz}\right) .{ }^{19} \mathrm{~F}$ NMR $\delta\left(\mathrm{ppm}, \mathrm{CDCl}_{3}\right):-126.07\left(\mathrm{t}, 2 \mathrm{~F}, \mathrm{CH}_{2}-\mathrm{CF}_{2}-\right.$ $\left.\mathrm{CF}_{2}-\mathrm{CF}_{2}-\mathrm{CF}_{3}\right),-124.52\left(\mathrm{t}, 2 \mathrm{~F}, \mathrm{CF}_{2}-\mathrm{CF}_{2}-\mathrm{CF}_{2}-\mathrm{CF}_{3}\right),-114.6(\mathrm{t}, 2 \mathrm{~F}$, $\left.\mathrm{CH}_{2}-\mathrm{CF}_{2}-\mathrm{CF}_{2}-\mathrm{CF}_{2}-\mathrm{CF}_{3}\right),-81.06\left(\mathrm{t}, 3 \mathrm{~F}, \mathrm{CF}_{3}\right) .{ }^{13} \mathrm{C} \mathrm{NMR} \delta\left(\mathrm{CDCl}_{3}\right)$ : $19.80\left(\mathrm{CH}_{2}-\mathrm{CH}_{2}-\mathrm{CF}_{2}\right), 20.55,20.58,20.65,20.78,20.89\left(\mathrm{CH}_{3}\right.$, OAc), $25.41\left(\mathrm{CH}_{2}\right), 29.05\left(\mathrm{CH}_{2}-\mathrm{CF}_{2}\right), 30.65\left(\mathrm{t}, \mathrm{CF}_{2} \mathrm{CH}_{2}\right), 61.50$ (C6'), 62.80 (C6), 68.02 (C5'), 68.48 (C4), 69.33 (C3'), 69.47 $\left(\mathrm{CH}_{2} \mathrm{O}\right), 69.99$ (C2') 72.13 (C5), 72.18 (C2), 72.74 (C4), 75.40 (C3), $95.52\left(\mathrm{C}^{\prime}\right), 100.25$ (C1), 170.52, 170.43, 170.24, 169.96, 169.56, $169.40\left(\mathrm{C}=\mathrm{O}\right.$, OAc). ESI-TOF MS: $[\mathrm{M}+\mathrm{H}]^{1+}$ 925.2.

$6^{\prime}, 6^{\prime}, 7^{\prime}, 7^{\prime}, 8^{\prime}, 8^{\prime}, 9^{\prime}, 9^{\prime}, 9^{\prime}$-Nonafluorononanyl-4-O-( $\alpha$-D-glucopyranosyl)- $\boldsymbol{\beta}$-D-glucopyranoside $\left(\mathbf{F}_{\mathbf{4}} \mathbf{H}_{\mathbf{5}} \boldsymbol{\beta} \mathbf{M}\right)$. The compound 2 (0.48 g) was dissolved in anhydrous methanol and sodium methoxide was added ( $\mathrm{pH}$ 8-9). The solution was stirred at ambient temperature until TLC revealed the reaction to be complete. It was neutralized using Amberlyst IR 50S ion-exchanger resin (protonated form), filtered, and evaporated in vacuo. The crude product was purified by chromatography on silica gel (EtOAc/MeOH/ $\left.\mathrm{H}_{2} \mathrm{O}: 8 / 1 / 1\right)$ to give $0.23 \mathrm{~g}$ of $\mathbf{F}_{\mathbf{4}} \mathbf{H}_{5} \mathbf{\beta} \mathbf{M}$ as a white powder (70\%).

${ }^{1} \mathrm{H}$ NMR $\delta\left(\mathrm{CD}_{3} \mathrm{OD}\right): 1.4\left(\mathrm{~m}, 2 \mathrm{H}, \mathrm{O}-\left(\mathrm{CH}_{2}\right)_{2}-\mathrm{CH}_{2}-\left(\mathrm{CH}_{2}\right)_{2}-\mathrm{CF}_{2}\right)$, $1.54\left(\mathrm{~m}, 4 \mathrm{H}, \mathrm{CH}_{2}-\mathrm{CH}_{2}-\mathrm{CF}_{2}, \mathrm{CH}_{2}-\mathrm{CH}_{2}-\mathrm{O}\right), 2.1\left(2 \mathrm{H}, \mathrm{m}, \mathrm{CH}_{2}-\mathrm{CF}_{2}\right)$, 3.11-3.81 (complex signal, $17 \mathrm{H}, \mathrm{H}$ glycosyl and $\mathrm{CH}_{2} \mathrm{O}$ ), 4.174.19 (d, $\left.1 \mathrm{H}, \mathrm{H} 1,{ }^{3} J_{1,2}=8 \mathrm{~Hz}\right), 5.06-5.07\left(\mathrm{~d}, 1 \mathrm{H}, \mathrm{H} 1^{\prime},{ }^{3} J_{1^{\prime}, 2^{\prime}}=4 \mathrm{~Hz}\right)$. ${ }^{19} \mathrm{~F}$ NMR $\delta\left(\mathrm{CD}_{3} \mathrm{OD}\right):-127.3\left(\mathrm{t}, 2 \mathrm{~F}, C_{2}-\mathrm{CF}_{3}\right),-125.55(\mathrm{t}, 2 \mathrm{~F}$, $\left.\mathrm{CF}_{2}-\mathrm{CF}_{2}-\mathrm{CF}_{2}-\mathrm{CF}_{3}\right),-115.67$ (t, 2F, $\mathrm{CH}_{2}-\mathrm{CF}_{2}-\mathrm{CF}_{2}-\mathrm{CF}_{2}-\mathrm{CF}_{3}$ ), $-81.70\left(\mathrm{t}, 3 \mathrm{~F}, \mathrm{CF}_{3}\right) .{ }^{13} \mathrm{C} \mathrm{NMR} \delta\left(\mathrm{CD}_{3} \mathrm{OD}\right): 21.06\left(\mathrm{CH}_{2} \mathrm{CH}_{2} \mathrm{CF}_{2}\right)$, $26.58\left(\mathrm{CH}_{2}-\mathrm{CH}_{2}-\mathrm{CH}_{2}-\right), 30.38\left(\mathrm{t}, \mathrm{CH}_{2}-\mathrm{CF}_{2}\right), 31.60\left(\mathrm{CH}_{2} \mathrm{CF}_{2}\right)$, 62.18 (C6), $62.75\left(\mathrm{C6}^{\prime}\right), 70.42\left(\mathrm{CH}_{2} \mathrm{O}\right), 71.50\left(\mathrm{C}^{\prime}\right), 74.17\left(\mathrm{C5}^{\prime}\right)$, 74.70 (C2), $74.79\left(\mathrm{C}^{\prime}\right), 75.08\left(\mathrm{C}^{\prime}\right), 76.59$ (C5), 77.87 (C3), 81.35 (C4), $102.93\left(\mathrm{C1}^{\prime}\right), 104.33$ (C1). ESI-TOF HRMS: calcd for $\mathrm{C}_{21} \mathrm{H}_{32} \mathrm{~F}_{9} \mathrm{O}_{11}[\mathrm{M}+\mathrm{H}]^{1+}$ 631.1800, found 631.1774.

$8^{\prime}$-Nonenyl tri-O-acetyl-4-O-(2,3,4,6-tetra-O-acetyl- $\alpha$-D-glucopyranosyl)- $\beta$-D-glucopyranoside (compound 3 ). The reaction was carried out as described for compound 2, using $5 \mathrm{~g}$ of peracetylated maltose (7.3 $\mathrm{mmol}), 3.49 \mathrm{~g}$ of 8-nonenol $(11.3 \mathrm{~mol})$ and $\mathrm{BF}_{3}-\mathrm{Et}_{2} \mathrm{O}(0.45 \mathrm{~mL})$ in dry dichloromethane $(6 \mathrm{~mL})$. After reacetylation with $\mathrm{Ac}_{2} \mathrm{O}(6 \mathrm{~mL})$ the product was purified by column chromatography (EtOAc/cyclohexane: 6/4) and recrystallization (EtOAc/heptane). We obtained $2.07 \mathrm{~g}$ of compound 3 as a white powder $(34 \%)$.

${ }^{1} \mathrm{H}-\mathrm{NMR} \delta\left(\mathrm{CDCl}_{3}\right): 1.21-1.55\left(\mathrm{~m}, 12 \mathrm{H},\left(\mathrm{CH}_{2}\right)_{6}\right), 1.93-2.07(\mathrm{~m}$, $\left.23 \mathrm{H}, \mathrm{CH}_{3} \mathrm{CO}\right), 3.45\left(\mathrm{~m}, 1 \mathrm{H}, \mathrm{OCH}_{2}\right), 3.7(\mathrm{~m}, 1 \mathrm{H}, \mathrm{H} 5), 3.8(\mathrm{~m}, 1 \mathrm{H}$, $\left.\mathrm{OCH}_{2}\right), 3.9-4.2(\mathrm{~m}, 4 \mathrm{H}), 4.25(\mathrm{~m}, 2 \mathrm{H}), 4.5(\mathrm{~m}, 2 \mathrm{H}, \mathrm{H} 1, J=7,5 \mathrm{~Hz})$, 4.75-4.9 (m, $2 \mathrm{H}), 5.0-5.1$ (m, 1H), 5.2-5.3 (m, 1H), 5.31-5.45 $\left(\mathrm{m}, 2 \mathrm{H}, \mathrm{H}^{\prime} 1\right)$, $5.58(\mathrm{~m}, 3 \mathrm{H}$, vinyl function), 5.7-5.8 (m, $1 \mathrm{H}$, $\left.\mathrm{CH}_{2}=\mathrm{CH}\right) .{ }^{13} \mathrm{C} \mathrm{NMR} \delta\left(\mathrm{CDCl}_{3}\right): 20.56,20.59,20.61,20.67,20.83$, $20.91\left(\mathrm{CH}_{3} \mathrm{CO}\right), 25.73,28.80,29.01,29.10,29.34\left(\mathrm{OCH}_{2}-\left(\mathrm{CH}_{2}\right)_{7}-\right.$ $\mathrm{CH}_{2}-\mathrm{CF}_{2}$ ), $33.72\left(\mathrm{CH}_{2}-\mathrm{CF}_{2}\right), 61.51\left(\mathrm{C6}^{\prime}\right), 62.90$ (C6), $68.03\left(\mathrm{C5}^{\prime}\right)$, 68.46 (C4), $69.35\left(\mathrm{C}^{\prime}\right), 69.98\left(\mathrm{CH}_{2} \mathrm{O}\right), 70.16\left(\mathrm{C}^{\prime}\right) 72.05$ (C5), 72.22 (C2), 72.78 (C4), 75.46 (C3), 95.49 (C1'), 100.28 (C1), $114.21\left(\mathrm{CH}_{2}=\mathrm{CH}\right), 139.05\left(\mathrm{CH}_{2}=\mathrm{CH}\right), 169.41,169.58,169.95$, $170.26,170.48,170.52(\mathrm{C}=\mathrm{O}, \mathrm{OAc})$. 
$8^{\prime}$-Iodo-10' $\mathbf{1 0}^{\prime}, \mathbf{1 1}^{\prime}, \mathbf{1 1}^{\prime}, \mathbf{1 1}^{\prime}$-pentafluoroundecyl tri-O-acetyl-4$O$-(2,3,4,6-tetra- $O$-acetyl- $\alpha$-D-glucopyranosyl)- $\beta$-D-glucopyranoside (compound 4). A solution of compound 3 (1.56 g, $2.05 \mathrm{mmol}$ ) in THF $(10 \mathrm{~mL})$ was placed in a Schlenk flask under argon. The flask was cooled at $-80{ }^{\circ} \mathrm{C}$ and a large excess of perfluoroiodoethane $(4 \mathrm{~mL})$ and $1 \mathrm{M} \mathrm{Et}_{3} \mathrm{~B}(1 \mathrm{~mL})$ was introduced. The mixture was stirred overnight at ambient temperature. After the evaporation of the solvent, the residue was diluted in ethyl acetate $(50 \mathrm{~mL})$ and washed successively with saturated $\mathrm{Na}_{2} \mathrm{~S}_{2} \mathrm{O}_{3}$ solution and water. The organic layer was dried over anhydrous sodium sulfate and evaporated to dryness. The crude product was purified by column chromatography on silica gel (cyclohexane/EtOAc: 1/1) and recrystallized in ethanol to give $1.94 \mathrm{~g}$ (94\%) of pure compound 4 as a white powder.

${ }^{1} \mathrm{H}-\mathrm{NMR} \delta\left(\mathrm{CDCl}_{3}\right): 1.32-1.59\left(\mathrm{~m}, 10 \mathrm{H},\left(\mathrm{CH}_{2}\right)_{5}-\mathrm{CH}_{2}-\mathrm{CHI}-\right)$, 1.7-1.85 ( $\left.\mathrm{CH}_{2}-\mathrm{CHI}\right), 2.01-2.15\left(\mathrm{~m}, 23 \mathrm{H}\right.$, acetyl groups, $\left.\mathrm{CH}_{2}-\mathrm{CF}_{2}\right)$, 2.6-2.95 (m, 1H, CHI), $3.45\left(\mathrm{~m}, 1 \mathrm{H}, \mathrm{O}-\mathrm{CH}_{2}\right), 3.65(\mathrm{~m}, 1 \mathrm{H}, \mathrm{H} 5)$, 3.84 (m, 1H, O- $\mathrm{CH}_{2}$ ), 3.9-4.06 (m, 3H, H4, H5', H6' a), 4.20-4.27 (m, 2H, H6b, H6b') 4.46 (d, 1H, H6a), 4.5-4.51-4.53 (m, 1H, $\left.\mathrm{H} 1,{ }^{3} J_{1,2}=8 \mathrm{~Hz}\right), 4.80-4.88\left(\mathrm{~m}, 2 \mathrm{H}, \mathrm{H} 2, \mathrm{H} 2^{\prime}\right), 5.06\left(\mathrm{t}, 1 \mathrm{H}, \mathrm{H} 4^{\prime}\right)$, 5.37 (t, 1H, H3 $\left.{ }^{\prime}, \mathrm{H} 3\right), 5.42$ (d, $\left.1 \mathrm{H}, \mathrm{H} 1^{\prime},{ }^{3} J_{1,2}=4 \mathrm{~Hz}\right) .{ }^{19} \mathrm{~F}$ NMR $\delta\left(\mathrm{ppm}, \mathrm{CDCl}_{3}\right)$ : $-85.82\left(\mathrm{CF}_{3}\right),-115.3$ to $-119.2\left(\mathrm{dd}, \mathrm{CF}_{2}\right)$. ${ }^{13} \mathrm{C}$ NMR $\delta\left(\mathrm{CDCl}_{3}\right): 20.57,20.60,20.65,20.68,20.84,20.91$ $\left(\mathrm{CH}_{3} \mathrm{CO}\right), 25.71,28.43,29.04,29.31,29.47\left(\mathrm{OCH}_{2}-\left(\mathrm{CH}_{2}\right)_{7}-\mathrm{CH}_{2}-\right.$ $\mathrm{CF}_{2}$ ), $40.16(\mathrm{CHI}), 41.48\left(\mathrm{t}, \mathrm{CH}_{2}-\mathrm{CF}_{2}\right), 61.50$ (C6'), 62.88 (C6), $68.03\left(\mathrm{C5}^{\prime}\right), 68.47(\mathrm{C} 4), 69.35\left(\mathrm{C}^{\prime}\right), 69.99\left(\mathrm{CH}_{2} \mathrm{O}\right), 70.09\left(\mathrm{C}^{\prime}\right)$; 72.22 (C2, C5), 72.76 (C4), 75.45 (C3), 95.50 (C1'), 100.30 (C1), 169.41, 169.57, 169.95, 170.26, 170.46, 170.53 (C=O, OAc). ESI-TOF HRMS: calcd for $\mathrm{C}_{37} \mathrm{H}_{53} \mathrm{O}_{18} \mathrm{~F}_{5} \mathrm{I}[\mathrm{M}+\mathrm{H}]^{1+} 1007.2197$ found 1007.2214.

$10^{\prime}, \mathbf{1 0}^{\prime}, \mathbf{1 1}^{\prime}, \mathbf{1 1}^{\prime}, \mathbf{1 1}^{\prime}$-Pentafluoroundec-8'-enyl tri- $O$-acetyl-4- $O$ $(2,3,4,6$-tetra- $O$-acetyl- $\alpha$-D-glucopyranosyl)- $\beta$-D-glucopyranoside (compound 5). A mixture of compound 4 (1.94 g, $1.9 \mathrm{mmol})$ and DBU (0.317 mL, 1.1 eq.) was placed in a $50 \mathrm{~mL}$ round-bottomed flask and stirred at $70{ }^{\circ} \mathrm{C}$ for $3 \mathrm{~h}$ until the disappearance of the iodoalkane (TLC monitoring). The crude mixture was washed successively with $1 \mathrm{~N} \mathrm{HCl}$, saturated $\mathrm{NaHCO}_{3}$, saturated $\mathrm{Na}_{2} \mathrm{~S}_{2} \mathrm{O}_{3}$, and water. The organic layer was dried over anhydrous sodium sulfate and evaporated to dryness. The crude product $5(1.56 \mathrm{~g}, 92 \%)$ was analyzed without purification using ${ }^{1} \mathrm{H}$ NMR and ${ }^{19} \mathrm{~F}$ NMR to check the complete dehydrohalogenation of compound 4 before catalytic hydrogenation. We observed a doubling of the peaks of vinyl carbons and most carbons of the molecule, leading to the conclusion that both cis- and transisomers coexist in the sample.

${ }^{1} \mathrm{H}-\mathrm{NMR} \delta\left(\mathrm{CDCl}_{3}\right): 1.2-1.9\left(\mathrm{~m}, 12 \mathrm{H},\left(\mathrm{CH}_{2}\right)_{6}\right), 1.9-2.1(\mathrm{~m}$, $\left.21 \mathrm{H}, \mathrm{CH}_{3} \mathrm{CO}\right), 3.45\left(\mathrm{~m}, 1 \mathrm{H}, \mathrm{OCH}_{2}\right), 3.7$ (m, 1H, H5), $3.85(\mathrm{~m}, 1 \mathrm{H}$, $\mathrm{OCH}_{2}$ ), 3.9-4.3 (m, 5H, 3H, H4, H5' , H6), 4.5 (m, 2H, H6, H1, J = $7.5 \mathrm{~Hz}), 4.75-4.9\left(\mathrm{~m}, 2 \mathrm{H}, \mathrm{H} 2, \mathrm{H} 2^{\prime}\right), 5.1\left(\mathrm{t}, 1 \mathrm{H}, \mathrm{H} 4^{\prime}\right), 5.25(\mathrm{t}, 1 \mathrm{H}$, $\left.\mathrm{H}^{\prime}\right), 5.35(\mathrm{t}, 1 \mathrm{H}, \mathrm{H} 3), 5.45\left(\mathrm{~d}, 1 \mathrm{H}, \mathrm{H}^{\prime}\right), 5.5-5.65(\mathrm{~m}, 1 \mathrm{H}$, $\left.-\mathrm{CH}=\mathrm{CH}-\mathrm{CF}_{2}\right), 6.35-6.45\left(\mathrm{~m}, 1 \mathrm{H},-\mathrm{CH}=\mathrm{CH}-\mathrm{CF}_{2}\right) .{ }^{19} \mathrm{~F}$ NMR $\delta$ $\left(\mathrm{ppm}, \mathrm{CDCl}_{3}\right):-85.42\left(\mathrm{CF}_{3}\right),-115.06\left(\mathrm{CF}_{2}\right) .{ }^{13} \mathrm{C} \mathrm{NMR} \delta\left(\mathrm{CDCl}_{3}\right)$ : 20.54, 20.56, 20.64, 20.79, $20.88\left(\mathrm{CH}_{3}, \mathrm{OAc}\right), 25.67,25.84,28.85$, 28.97, 29.22, 29.30, 31.89, $33.64\left(\mathrm{CH}_{2}\right), 61.52,62.00\left(\mathrm{C6}^{\prime}\right), 62.88$, (C6), 68.05 (C5'), 68.47 (C4), $69.35\left(\mathrm{C}^{\prime}\right), 70.00,70.04\left(\mathrm{CH}_{2} \mathrm{O}\right)$, 71.35, 71.75 (C2'), 72.09 (C5), 72.23 (C2), 72.81, 72.85 (C4),
75.43 (C3), 95.51 (C1'), 100.28, 100.81 (C1), 114.41, 116.60 $\left(\mathrm{CF}_{2}-\mathrm{CH}=\right), 138.74,142.98(=\mathrm{CH}), 170.50,170.43,170.29,170.23$, 169.93, 169.54, 169.38, 169.23 ( $\mathrm{C}=\mathrm{O}$, OAc). ESI-TOF HRMS: calcd for $\mathrm{C}_{37} \mathrm{H}_{52} \mathrm{O}_{18} \mathrm{~F}_{5}[\mathrm{M}+\mathrm{H}]^{1+} 879.3074$ found 879.3074.

$10^{\prime}, \mathbf{1 0}^{\prime}, \mathbf{1 1}^{\prime}, \mathbf{1 1}^{\prime}, \mathbf{1 1}^{\prime}$-Pentafluoroundecyl tri-O-acetyl-4-O-(2,3,4,6tetra- $O$-acetyl- $\alpha$-D-glucopyranosyl)- $\beta$-D-glucopyranoside (compound 6). A mixture of compound 5 (1.5 g, $17.08 \mathrm{mmol})$ and palladium on charcoal $\mathrm{Pd}-\mathrm{C}(30 \mathrm{mg})$ in methanol $(20 \mathrm{~mL})$ was stirred under $7 \mathrm{~atm}$ of hydrogen for $16 \mathrm{~h}$. The catalyst was filtered through a celite pad. The filtrate was concentrated in a vacuum and the residue was purified by column chromatography (cyclohexane/ EtOAc $4: 6)$ to afford compound $6(1.25 \mathrm{~g})$ with $83 \%$ yield. The product was recrystallized in hot methanol to give compound 6 as a pure white powder.

${ }^{1} \mathrm{H}-\mathrm{NMR} \delta\left(\mathrm{CDCl}_{3}\right): 1.23-1.6\left(\mathrm{~m}, 8 \mathrm{H}, \mathrm{CH}_{2}-\left(\mathrm{CH}_{2}\right)_{3}-\mathrm{CH}_{2}-\mathrm{CF}_{2}-\right)$, 1.96-2.14 (m, 23H, acetyl groups, $\left.\mathrm{CH}_{2}-\mathrm{CF}_{2}\right), 3.45(\mathrm{~m}, 1 \mathrm{H}$, O- $\mathrm{CH}_{2}$ ), 3.65 (m, 1H, H5), $3.86\left(\mathrm{~m}, 1 \mathrm{H}, \mathrm{O}-\mathrm{CH}_{2}\right), 3.98-4.06(\mathrm{~m}$, $3 \mathrm{H}, \mathrm{H}^{\prime}{ }^{\prime}, \mathrm{H}^{\prime}$, H6a), 4.24 (m, 2H, H6b, H6' a), 4.45-4.49 (dd, 1H, $\left.\mathrm{H}^{\prime} \mathrm{b}\right), 4.50-4.52\left(\mathrm{~m}, 1 \mathrm{H}, \mathrm{H} 1,{ }^{3} J_{1,2}=8 \mathrm{~Hz}\right), 4.82-4.88(\mathrm{~m}, 2 \mathrm{H}, \mathrm{H} 2$, $\left.\mathrm{H} 2^{\prime}\right), 5.08$ (t, 1H, H4), 5.25 (t, 1H, H3 $\left.{ }^{\prime}\right), 5.36$ (t, 1H, H3, H3), 5.41-5.42 (d, $\left.1 \mathrm{H}, \mathrm{H}^{\prime},{ }^{3} J_{1,2}=4 \mathrm{~Hz}\right) .{ }^{19} \mathrm{~F}$ NMR $\delta$ (ppm, CDCl3): $-118.24\left(\mathrm{t}, 2 \mathrm{~F},-\mathrm{CF}_{2}-\mathrm{CF}_{3}\right),-85.44\left(\mathrm{~s}, 3 \mathrm{~F}, \mathrm{CF}_{2}-C F_{3}\right) .{ }^{13} \mathrm{C} \mathrm{NMR} \delta$ $\left(\mathrm{CDCl}_{3}\right): 19.80\left(\mathrm{CH}_{2}-\mathrm{CH}_{2}-\mathrm{CF}_{2}\right), 20.55,20.58,20.65,20.78,20.89$ $\left(\mathrm{CH}_{3}, \mathrm{OAc}\right), 25.41\left(\mathrm{CH}_{2}\right), 29.05\left(\mathrm{CH}_{2}-\mathrm{CH}_{2} \mathrm{O}\right), 30.65\left(\mathrm{t}, \mathrm{CF}_{2} \mathrm{CH}_{2}\right)$, 61.50 (C6'), 62.80 (C6), 68.02 (C5'), 68.48 (C4), 69.33 (C3'), 69.47 $\left(\mathrm{CH}_{2} \mathrm{O}\right), 69.99\left(\mathrm{C}^{\prime}\right) 72.13$ (C5), 72.18 (C2), 72.74 (C4), 75.40 (C3), 95.52 (C1'), 100.25 (C1), 170.52, 170.43, 170.24, 169.96, 169.56, $169.40\left(\mathrm{C}=\mathrm{O}\right.$, OAc). ESI-TOF HRMS: calcd for for $\mathrm{C}_{37} \mathrm{H}_{54} \mathrm{O}_{18} \mathrm{~F}_{5}$ $[\mathrm{M}+\mathrm{H}]^{1+} 881.3230$, found 881.3245.

$10^{\prime}, \mathbf{1 0}^{\prime}, \mathbf{1 1}^{\prime}, \mathbf{1 1}^{\prime}, \mathbf{1 1}^{\prime}$-Pentafluoroundecyl 4-O-( $\alpha$-D-glucopyranosyl)$\boldsymbol{\beta}$-D-glucopyranoside $\left(\mathbf{F}_{\mathbf{2}} \mathbf{H}_{\mathbf{9}} \boldsymbol{\beta} \mathbf{M}\right)$. The compound $\mathbf{6}(0.8 \mathrm{~g})$ was dissolved in anhydrous methanol and sodium methoxide was added ( $\mathrm{pH}$ 8-9). The solution was stirred at ambient temperature until TLC revealed the reaction to be complete. It was neutralized using Amberlyst IR 50S ion-exchanger resin (protonated form), filtered, and evaporated in a vacuum. The crude product was purified by chromatography on silica gel (EtOAc/ $\mathrm{MeOH} / \mathrm{H}_{2} \mathrm{O}: 8 / 1 / 1$ ) to give $0.5 \mathrm{~g}$ of $\mathbf{F}_{2} \mathbf{H}_{9} \mathbf{\beta} \mathbf{M}$ as a white powder (93\%).

${ }^{1} \mathrm{H}$ NMR $\delta\left(\mathrm{CD}_{3} \mathrm{OD}\right): 1.3-1.5\left(\mathrm{~m}, 10 \mathrm{H}, \mathrm{O}-\left(\mathrm{CH}_{2}\right)_{2}-\left(\mathrm{CH}_{2}\right)_{5^{-}}\right.$ $\left(\mathrm{CH}_{2}\right)_{2}-\mathrm{CF}_{2}-$ ), 1.55-1.63 (m, 4H, $\left.\mathrm{CH}_{2}-\mathrm{CH}_{2}-\mathrm{CF}_{2}, \mathrm{CH}_{2}-\mathrm{CH}_{2}-\mathrm{O}\right)$, 2.08-2.12 (2H, m, $\mathrm{CH}_{2}-\mathrm{CF}_{2}$ ), 3.21-3.91 (complex signal, $17 \mathrm{H}, \mathrm{H}$ glycosyl and $\left.\mathrm{CH}_{2} \mathrm{O}\right), 4.27-4,29\left(\mathrm{~d}, 1 \mathrm{H}, \mathrm{H} 1,{ }^{3} J_{1,2}=8 \mathrm{~Hz}\right), 5.16-5.17$ (d, $\left.1 \mathrm{H}, \mathrm{H} 1^{\prime},{ }^{3} J_{1^{\prime}, 2^{\prime}}=4 \mathrm{~Hz}\right) .{ }^{19} \mathrm{~F}$ NMR $\delta\left(\mathrm{CD}_{3} \mathrm{OD}\right):-119.39(2 \mathrm{~F}$, $\left.\mathrm{CF}_{2}-\mathrm{CF}_{3}\right),-87.00 \quad\left(3 \mathrm{~F}, \mathrm{CF}_{3}\right) .{ }^{13} \mathrm{C} \quad \mathrm{NMR} \quad \delta \quad\left(\mathrm{CD}_{3} \mathrm{OD}\right): 21.43$ $\left(\mathrm{CH}_{2} \mathrm{CH}_{2} \mathrm{CF}_{2}\right), 27.07,30.11,30.29,30.46,30.48,30.78\left(\left(\mathrm{CH}_{2}\right)_{n}\right)$, 31.49 (t, $\left.\mathrm{CH}_{2} \mathrm{CF}_{2}\right), 62.22$ (C6), $62.79\left(\mathrm{C6}^{\prime}\right), 70.94\left(\mathrm{CH}_{2} \mathrm{O}\right), 71.56$ $\left(\mathrm{C}^{\prime}\right)$, $74.19\left(\mathrm{C5}^{\prime}\right), 74.73(\mathrm{C} 2), 74.79\left(\mathrm{C}^{\prime}\right), 75.11\left(\mathrm{C}^{\prime}\right), 76.62(\mathrm{C} 5)$, 77.90 (C3), 81.36 (C4), 102.93 (C1'), 104.34 (C1). ESI-TOF HRMS: calcd for $\mathrm{C}_{23} \mathrm{H}_{40} \mathrm{~F}_{5} \mathrm{O}_{11}[\mathrm{M}+\mathrm{H}]^{1+}$ 587.2491, found 587.2489.

\section{Techniques}

\section{Surface tensiometry}

After dissolving the surfactants in Milli-Q water, surface tensiometry (ST) was performed with the aid of a K100 tensiometer 
(Kruss, Hamburg, Germany) using the Wilhelmy plate technique. Surfactant solutions at 5-10 times the expected CMC were prepared $24 \mathrm{~h}$ prior to measurements, and $20 \mathrm{~mL}$ of the sample was transferred to a $50 \mathrm{~mL}$ vessel supplied with a stir bar. Surface tensions were determined by the automatic dilution of the stock solutions using a Metrohm 700 Dosino. In a typical experiment, 100 concentration steps were used with $\sim 20$ min between consecutive concentration steps. The platinum plate was cleaned by flaming before each experiment. The glassware was cleaned with sulfochromic solution and rinsed with Milli-Q water. All measurements were performed at $20{ }^{\circ} \mathrm{C}$. Sets of measurements to obtain equilibrium surface tension were taken until the change in surface tension was less than $0.01 \mathrm{mN} \mathrm{m}^{-1}$. The CMC and the surface tension at the CMC $\left(\gamma_{\mathrm{CMC}}\right)$ were determined from, respectively, the abscissa and the ordinate at the break point of the $\gamma-\log C$ curve. The maximum surface excess $\Gamma_{\max }$ was calculated using the following Gibbs adsorption isotherm equation: ${ }^{25}$

$$
\Gamma_{\max }=-(1 / R T)(\mathrm{d} \gamma / \mathrm{d} \ln C)
$$

where $\gamma$ is the surface tension in $\mathrm{mN} \mathrm{m}^{-1}, \Gamma_{\max }$ is the maximum

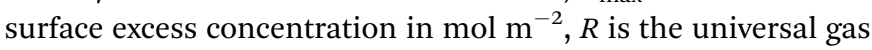
constant ( $8.31 \mathrm{~J} \mathrm{~mol}^{-1} \mathrm{~K}^{-1}$ ), $T$ is the absolute temperature, $C$ is the surfactant concentration, and $(\mathrm{d} \gamma / \mathrm{d} \ln C)$ is the slope below the $\mathrm{CMC}$ in the surface tension plots. The minimum area occupied per surfactant molecule at the air/water interface $\left(A_{\text {min }}\right.$, in $\AA^{2}$ ) is related to $\Gamma_{\text {max }}$ by the relation $A_{\min }=10^{16} / N_{\mathrm{a}} \Gamma_{\max }$, where $N_{\mathrm{a}}$ is Avogadro's number.

The standard Gibbs free energy of micellization is given by the following equation $\Delta G_{\text {mic }}^{\circ}=2.3 R T \log X_{\mathrm{CMC}}$, where $X_{\mathrm{CMC}}$ is the mole fraction of the surfactant in the liquid phase at the $\mathrm{CMC}$, that is, $X_{\mathrm{CMC}}=\mathrm{CMC} / 55.5 \mathrm{M}$ for surfactants in water. The standard Gibbs free energy of adsorption $\Delta G_{\text {ads }}^{\circ}$ is then given as follows $\Delta G_{\mathrm{ads}}^{\circ}=2.3 R T(\log \mathrm{CMC} / M-\log 55.5)-\prod_{\mathrm{CMC}} / \Gamma_{\max }$ with the surface pressure $\Pi_{\mathrm{CMC}}$ denoting the difference between the surface tension of pure water $\left(\gamma_{\mathrm{o}}\right)$ and that of the solution at the CMC $\left(\gamma_{\mathrm{CMC}}\right)$.

\section{${ }^{19}$ F NMR for CMC determination}

13 samples of each surfactant $\left(\mathbf{F}_{2} \mathbf{H}_{9} \boldsymbol{\beta} \mathbf{M}, \mathbf{F}_{\mathbf{4}} \mathbf{H}_{5} \boldsymbol{\beta} \mathbf{M}\right.$, and $\left.\mathrm{F}_{6} \mathrm{H}_{2} \beta \mathbf{M}\right)$ at different concentrations were prepared from stock solutions (2.5 $\mathrm{g} \mathrm{L}^{-1}$ for $\mathbf{F}_{2} \mathbf{H}_{9} \boldsymbol{\beta} \mathbf{M}$ and $\mathrm{F}_{6} \mathrm{H}_{2} \beta \mathrm{M}$ and $4 \mathrm{~g} \mathrm{~L}^{-1}$ for $\mathbf{F}_{4} \mathbf{H}_{5} \boldsymbol{\beta} \mathbf{M}$ ). The solutions were diluted by taking $4 \mathrm{~mL}$ of previous solutions to which $1 \mathrm{~mL}$ of a solution of water containing $1 \mathrm{mg}$ of $\mathrm{CF}_{3} \mathrm{COONa}$ was added. ${ }^{19} \mathrm{~F}$ NMR spectra were recorded on a Bruker Avance 400 spectrometer equipped with a pulse-field gradient module (Z-axis) using a $5 \mathrm{~mm}$ BBO probe. The instrument was operated at a frequency of $376.72 \mathrm{MHz}$ at $25{ }^{\circ} \mathrm{C}$. The observed chemical ("obs") shifts of the $\mathrm{CF}_{3}$ of the surfactants were examined as a function of concentration below and above the CMC. All samples were dissolved in $\mathrm{H}_{2} \mathrm{O}$, and chemical shifts were referenced to the center of the $\mathrm{CF}_{3} \mathrm{COONa}$ signal $(-73.53 \mathrm{ppm})$.

\section{Isothermal titration calorimetry}

Isothermal titration calorimetry (ITC) demicellization experiments were carried out on a VP-ITC (Malvern Instruments, Worcestershire, UK) at $21^{\circ} \mathrm{C}$. A surfactant solution at a concentration of 10-15 times the CMC was loaded in the syringe and titrated into tripledistilled water. Experimental settings included an injection volume of $5 \mu \mathrm{L}$, a reference power of $42-84 \mu \mathrm{J} \mathrm{s}^{-1}$, and a filter period of $2 \mathrm{~s}$. Time spacings between injections were set long enough to allow the power signal to reach the baseline before the next injection. Baseline adjustment and peak integration were accomplished using NITPIC. ${ }^{26}$ The first injection was always excluded from further analysis. For $\mathbf{F}_{\mathbf{2}} \mathbf{H}_{\mathbf{9}} \boldsymbol{\beta} \mathbf{M}$, demicellization isotherms were fitted using a generic sigmoid function to determine the CMC and the molar enthalpy of micellization, as explained elsewhere. ${ }^{27}$ Demicellization isotherms of $\mathbf{F}_{4} \mathbf{H}_{5} \boldsymbol{\beta} \mathbf{M}$ reproducibly revealed a local maximum within the transition region, which precluded such a detailed fit. Hence, the CMC was taken as the maximum in the first derivative of the heat of reaction with respect to surfactant concentration, and the molar enthalpy of micellization was determined from the difference between linear pre- and post-transition baselines at the CMC.

\section{Analytical ultracentrifugation (AUC) sedimentation velocity}

Stock solutions at $15 \mathrm{~g} \mathrm{~L}^{-1}$ in water were prepared, and diluted samples of $\mathbf{F}_{2} \mathbf{H}_{9} \boldsymbol{\beta} \mathbf{M}$ at 8, 6, 4, 2, 1, and $0.5 \mathrm{~g} \mathrm{~L}^{-1}$, of $\mathbf{F}_{\mathbf{4}} \mathbf{H}_{5} \boldsymbol{\beta} \mathbf{M}$ at 8, 6,4 , and $2 \mathrm{~g} \mathrm{~L}^{-1}$, and of $\mathrm{F}_{6} \mathrm{H}_{2} \beta \mathrm{M}$ at $15,10,7.5,5,2$, and $1 \mathrm{~g} \mathrm{~L}^{-1}$ were investigated by sedimentation velocity (SV) experiments, conducted in an XLI analytical ultracentrifuge (Beckman, Palo Alto, CA) using an ANTi-50 rotor and detected at $280 \mathrm{~nm}$ and with interference optics, at 42000 revolutions per min (rpm) and $20{ }^{\circ} \mathrm{C}$ overnight, using double-channel center pieces (Nanolytics, Germany) of 3 or $12 \mathrm{~mm}$ optical path length (the reference channel being filled with water) equipped with sapphire windows. Continuous distribution of sedimentation coefficients, $c(s)$, was derived using the SEDFIT software ${ }^{28}$ version 14.1 (freely available at: http://www.analyticalultracentrifugation.com), correcting for errors in the time acquisition of the acquisition software Proteomelab XLI V6.0. ${ }^{29}$ and analyzed as described in ref. 30, to obtain the CMC and refractive index increment, $\partial n / \partial c$, the sedimentation coefficient at infinite dilution $\left(s_{0}\right)$, and the concentration dependency factor $\left(k_{s}{ }^{\prime}\right){ }^{31}$ The value of $s_{0}$ is interpreted through the Svedberg equation, in terms of the molar mass, $M$, the hydrodynamic radius, $R_{\mathrm{H}}$, and the frictional ratio, $f / f_{\text {min }}$. We considered the partial specific volumes, $\bar{v}$, from ref. 32 reported in Table $\mathrm{S} 1$ (ESI $\dagger)$. Values calculated from chemical composition ${ }^{33}$ differ somewhat but are in the same range, that is, 0.718, 0.629, and $0.564 \mathrm{~mL} \mathrm{~g}^{-1}$ for $\mathbf{F}_{\mathbf{2}} \mathbf{H}_{\mathbf{9}} \boldsymbol{\beta} \mathbf{M}, \mathbf{F}_{\mathbf{4}} \mathbf{H}_{5} \boldsymbol{\beta} \mathbf{M}$, and $\mathrm{F}_{6} \mathrm{H}_{2} \beta \mathrm{M}$, respectively.

\section{Dynamic light scattering}

Dynamic light scattering (DLS) experiments were performed on a Zetasizer Nano-S model 1600 (Malvern Instruments, UK) equipped with a He-Ne laser $(\lambda=633 \mathrm{~nm})$ at an angle of $173^{\circ}$ (backscattering detection). Surfactant solutions were prepared $24 \mathrm{~h}$ prior to measurements using filtered Milli-Q water. Surfactant solutions were centrifuged at $15000 \mathrm{rpm}$ for $2 \mathrm{~h}$ before being transferred into a $45 \mu \mathrm{L}$ low-volume quartz batch cuvette (Hellma). Time-dependent correlation functions were measured for different concentrations of surfactants. The hydrodynamic radius $\left(R_{\mathrm{H}}\right)$ of micelles was calculated from 
extrapolation to zero concentration of diffusion coefficients, $D=D_{0}\left(1+k_{\mathrm{D}}(c-\mathrm{CMC})\right)$, using the Stokes-Einstein equation $D_{0}=k_{\mathrm{B}} T / 6 \pi \eta R_{\mathrm{H}}$, where $k_{\mathrm{B}}$ is Boltzmann's constant, $T$ is the absolute temperature, and $\eta$ is the viscosity of the solvent. $k_{\mathrm{D}}$ refers to an interaction parameter between micelles in solution. ${ }^{34}$ If $k_{\mathrm{D}}$ is positive (negative), the interactions between micelles are repulsive (attractive). All measurements were carried out at $20{ }^{\circ} \mathrm{C}$.

\section{Small-angle X-ray scattering}

Micellar assemblies in water were characterized by small-angle X-ray scattering (SAXS) on a bioSAXS beamline ID14-eh3 and BM29 ${ }^{35}$ at the European Synchrotron Radiation Facility in Grenoble, France. To prevent radiation damage during the scattering experiments, data were collected in 10 successive $2 \mathrm{~s}$ frames, and the solution was moved into the capillary during exposure. All measurements were carried out at $20{ }^{\circ} \mathrm{C}$. Averaged scattered intensities were subtracted from water. Forward scattering values (i.e., $q \rightarrow 0 ; \mathrm{I}(c, 0))$ and radii of gyration $\left(R_{\mathrm{G}}\right)$ were evaluated using the Guinier approximation $I(c, q)=I(0) \cdot \exp \left(-q^{2} R_{\mathrm{G}}^{2} / 3\right)$ assuming that $q R_{\mathrm{G}}<1$ at very small angles. CMCs of surfactants were determined from the plot of $I(c, 0)$ as a function of surfactant concentration. Molar masses and aggregation numbers of micelles were then calculated from the absolute forward intensity, normalized to a reference of pure water. ${ }^{36}$ The aggregation number $N_{\mathrm{agg}}$ was determined by dividing the micelle molar mass by that of the surfactant monomer:

$$
N_{\mathrm{agg}}=\left.N_{\mathrm{a}} \frac{I(0)_{\text {mic }}}{M_{\text {surf }}(c-\mathrm{CMC}) I(0)_{\text {water }}\left[r_{0} \cdot \bar{v}\left(\rho_{\text {surf }}-\rho^{0}\right)\right]^{2}} \frac{\mathrm{d} \Sigma}{\mathrm{d} \Omega}\right|_{\text {water }}
$$

with $N_{\mathrm{a}}$ denoting Avogadro's number, $r_{0}$ the classical electron radius $\left(r_{0}=0.28179 \times 10^{-12} \mathrm{~cm} \mathrm{e}^{-1}\right), \bar{v}$ the surfactant partial specific volume $\left(\mathrm{cm}^{3} \mathrm{~g}^{-1}\right), M_{\text {surf }}$ the surfactant molar mass, $\rho_{\text {surf }}$ and $\rho^{0}$ the scattering length densities of the surfactant and water $\left(\mathrm{e} \mathrm{cm}^{-3}\right)$, respectively, and $\mathrm{d} \Sigma /\left.\mathrm{d} \Omega\right|_{\text {water }}$ the absolute scattering intensity of water equal to $0.01632 \mathrm{~cm}^{-1}$ at $20^{\circ} \mathrm{C}$.

\section{Biochemistry}

The purified purple membrane was solubilized for $36 \mathrm{~h}$ at $4{ }^{\circ} \mathrm{C}$ with $52 \mathrm{mM} n$-octyl- $\beta$-D-thioglucoside (OTG; CMC $=9 \mathrm{mM}$ ) at a membrane concentration of $1.3 \mathrm{~g} \mathrm{~L}^{-1}$ in $20 \mathrm{mM}$ sodium phosphate buffer, $\mathrm{pH}$ 6.8. Samples were diluted to reach a final OTG concentration of $15 \mathrm{mM}$, supplemented with $3 \mathrm{mM}$ of the surfactant to be tested, and incubated for $15 \mathrm{~min}$ prior to being loaded onto a $10-30 \%(\mathrm{w} / \mathrm{w})$ sucrose gradient containing $20 \mathrm{mM}$ sodium phosphate buffer pH 6.8 and $6 \mathrm{mM}$ of the same surfactant. A control experiment was performed in a gradient containing $6 \mathrm{mM} \mathrm{\mathbf {H } _ { 1 2 }} \boldsymbol{\beta} \mathbf{M}$. Gradients were centrifuged for $5 \mathrm{~h}$ at $55000 \mathrm{rpm}(200000 \mathrm{~g})$ using a TLS55 rotor of a TL100 ultracentrifuge (Beckman). Bands containing the colored protein were collected with a syringe, and protein samples were kept at $4{ }^{\circ} \mathrm{C}$ in the dark for UV-visible spectrophotometry.

\section{Results and discussion}

\section{Synthesis of novel fluorinated maltosides}

Two novel fluorosurfactants were synthesized with the aim of emulating the structure and the overall hydrophilic/lipophobic balance of the commonly used detergent $\mathbf{H}_{\mathbf{1 2}} \boldsymbol{\beta} \mathbf{M}$. To this end, we modulated the length of hydrogenated and fluorinated segments, taking into account that the hydrophobic contribution of $\mathrm{CF}_{2}$ is about 1.5-1.7 times greater than that of $\mathrm{CH}_{2}$, depending on the nature of the polar head. ${ }^{37,38}$ In order to avoid the formation of large and polydisperse aggregates as previously observed with $\mathrm{F}_{6} \mathrm{H}_{3} \beta \mathrm{M}$ and $\mathrm{H}_{2} \mathrm{~F}_{6} \mathrm{H}_{3} \beta \mathrm{M},{ }^{22}$ we combined shorter fluorinated segments, namely, either a fluorinated segment of four carbons with a hydrogenated segment made of five carbons $\left(\mathbf{F}_{4} \mathbf{H}_{5} \mathbf{\beta M}\right)$ or a fluorinated segment of two carbons with an aliphatic segment comprising nine hydrogenated carbons $\left(\mathbf{F}_{2} \mathbf{H}_{9} \boldsymbol{\beta} \mathbf{M}\right)$. Two chemical pathways were used to prepare these two compounds.

Synthesis of $\mathbf{F}_{4} \mathbf{H}_{5} \boldsymbol{\beta} \mathbf{M}$. The most straightforward route for synthesizing these compounds consists in grafting the F-alkyl group on the double bond of a vinylic alcohol by the radical addition of a perfluorinated iodide in the presence of zinc as an initiator in dichloromethane (Scheme 2). ${ }^{39}$

The iodinated addition product was dehalogenated in a onepot reaction by the addition of acetic acid and $2 \mathrm{~N} \mathrm{HCl}$. The progress of the reaction was monitored by ${ }^{1} \mathrm{H}$ NMR spectroscopy. The iodinated and the dehalogenated products have the same ratio front in TLC. In a first step, we observed the complete disappearance of the vinylic signal and the formation of a multiplet corresponding to the CHI signal at $2.75 \mathrm{ppm}$. This signal disappeared after acidification of the reaction. After chromatography, the hemifluorinated alcohol 1 was obtained pure with a $70 \%$ overall yield. An effective method to graft maltose onto the alcohol $\mathbf{1}$ is Lewis acid-catalyzed glycosylation using maltose peracetate. Maltosidation of alcohol was carried out by the treatment of $\beta$-D-maltose peracetate with equimolar amounts of alcohols and $\mathrm{BF}_{3}-\mathrm{Et}_{2} \mathrm{O}$ in dry dichloromethane. ${ }^{40-42}$ Such Lewis acid glycosylation afforded the $\beta$-D-glucoside 2 with $32 \%$ yield after chromatography and crystallization with a high degree of stereoselectivity. $\beta$-Anomeric stereochemistry was expected for compound 2 and was confirmed by its ${ }^{1} \mathrm{H}$ NMR spectrum $(J=7.75 \mathrm{~Hz})$. However, the $\alpha$ isomer always contaminates the samples after glycosylation (5 to $10 \%$ ). Indeed it is impossible during glycosylation to have a $100 \%$ stereoselective reaction. Crystallization in ethanol is the most efficient methodology to completely remove the $\alpha$ anomer and obtain the $\beta$ anomer with a chiral purity higher than $99 \%$. We observed the formation of deacetylated compounds by transesterification. This side reaction uses large quantities of alcohol and contributes to greatly reduced yields of glycosylation. The addition of an acetic anhydride and pyridine mixture allowed reacetylation of partially deacetylated compounds and improved reaction yields after crystallization in ethanol. The remaining acetyl protecting groups in 2 were removed with $\mathrm{MeONa}$ in $\mathrm{MeOH}$ to provide $\mathbf{F}_{4} \mathbf{H}_{5} \boldsymbol{\beta} \mathbf{M}$ in good yield.

Synthesis of $\mathbf{F}_{2} \mathbf{H}_{9} \boldsymbol{\beta}$ M. The above route failed to provide $\mathbf{F}_{2} \mathbf{H}_{9} \boldsymbol{\beta} \mathbf{M}$. Whatever the hemifluorinated alcohol batch used, the glycosylation step did not work and made it necessary to adopt a different route for the synthesis of $\mathbf{F}_{2} \mathbf{H}_{\mathbf{9}} \boldsymbol{\beta} \mathbf{M}$. In this synthetic route, the hydrocarbon segment was first grafted onto the maltose. The fluorinated part was introduced in a second 

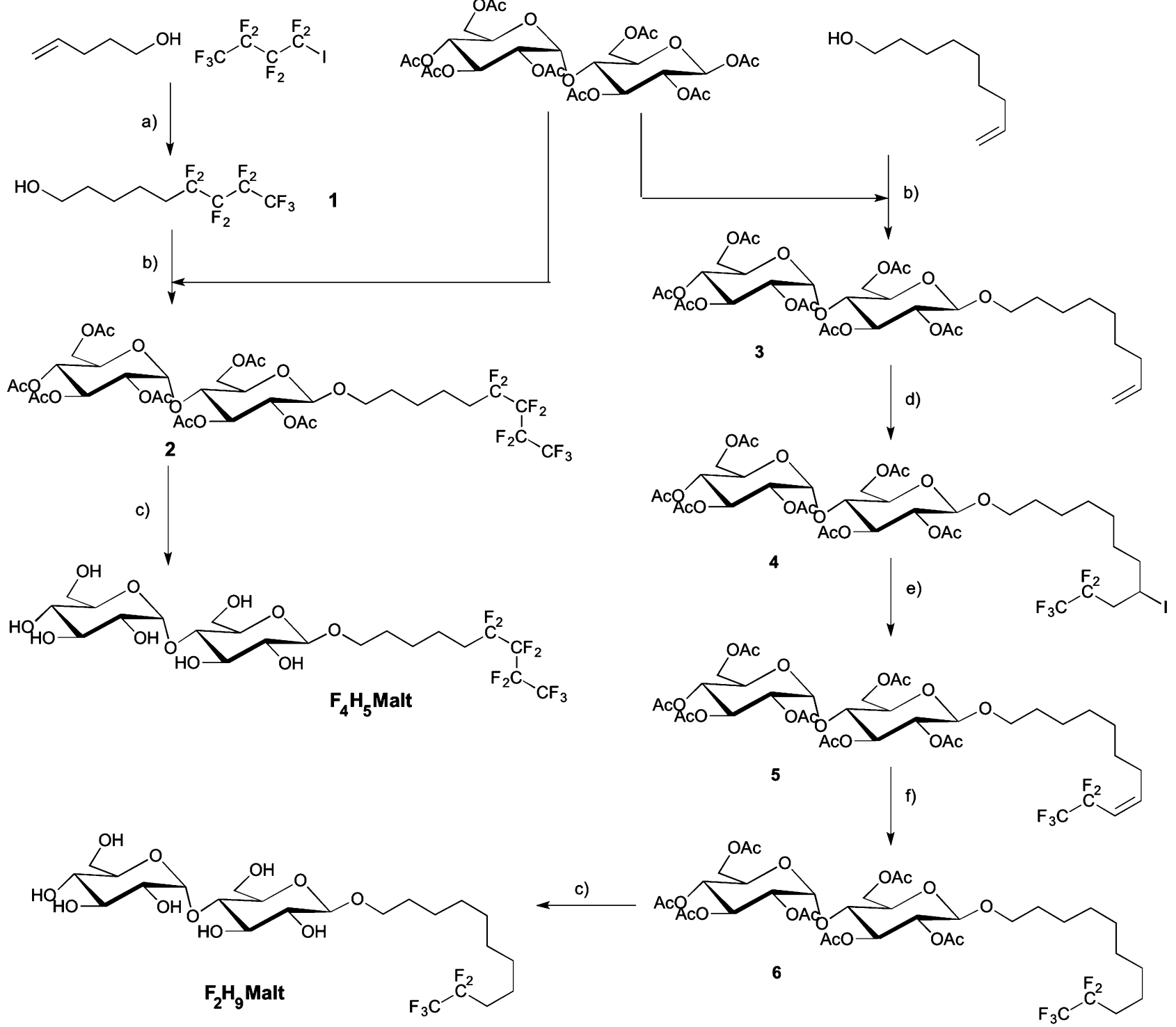

Scheme 2 Synthetic route leading to the poorly fluorinated $\mathbf{H}_{\mathbf{1 2}} \boldsymbol{\beta} \mathbf{M}$ derivatives $\mathbf{F}_{\mathbf{2}} \mathbf{H}_{\mathbf{9}} \boldsymbol{\beta} \mathbf{M}$ and $\mathbf{F}_{\mathbf{4}} \mathbf{H}_{\mathbf{5}} \mathbf{\beta} \mathbf{M}$ : (a) activated zinc, $\mathrm{CH}_{2} \mathrm{Cl}_{2}$, Argon, for $4 \mathrm{~h}$ then $\mathrm{H}_{2} \mathrm{O} / \mathrm{AcOH} / 12 \mathrm{~N} \mathrm{HCl}: 30 / 15 / 5,70 \%$; (b) $\mathrm{BF}_{3}-\mathrm{Et}_{2} \mathrm{O}, 0{ }^{\circ} \mathrm{C}, 24 \mathrm{~h}$, then $\mathrm{Ac}_{2} \mathrm{O}$ for $2 \mathrm{~h}, 32-34 \%$; (c) $\mathrm{MeONa}, \mathrm{MeOH}, \mathrm{rt}, 4 \mathrm{~h}, 70-94 \%$; (d) $\mathrm{CF}_{3} \mathrm{CF}_{2} \mathrm{l}, \mathrm{THF},-80{ }^{\circ} \mathrm{C} \mathrm{Et}_{3} \mathrm{~B}$, $24 \mathrm{~h}, 94 \%$; (e) $\mathrm{DBU}$, toluene, $70{ }^{\circ} \mathrm{C}, 3 \mathrm{~h}, 92 \%$; (f) $\mathrm{H}_{2}, \mathrm{Pd}-\mathrm{C}, \mathrm{MeOH}, 83 \%$.

stage by radical addition (Scheme 2). In a first step, nonenol was grafted on peracetylated maltoside in the presence of $\mathrm{BF}_{3}-\mathrm{Et}_{2} \mathrm{O}$. The transfer of the acetyl group from peracetylated maltose to the hydroxyl group of nonenol is an undesirable side reaction that often occurs during Lewis acid mediated glycosylations ${ }^{43}$ and led with low yield to compound 3 (20\%).

The $\beta$-anomeric configuration of 3 was confirmed by ${ }^{1} \mathrm{H}$ and ${ }^{13} \mathrm{C}$ NMR spectra. The addition of perfluoroethyl iodide in THF to the olefin 3 catalyzed by $\mathrm{Et}_{3} \mathrm{~B}$ was performed at low temperature in order to liquefy the perfluoroalkyl iodide at room temperature. The reaction was completed after $24 \mathrm{~h}$ and gave the adduct 4 in $94 \%$ yield. Dehalogenation had to be quantitative, as the deiodinated product and compound $\mathbf{4}$ had the same ratio front in TLC and were very difficult to separate. Reductive radical dehalogenation reactions with $\mathrm{Bu}_{3} \mathrm{SnH} / \mathrm{AIBN}$ or $\mathrm{Zn} / \mathrm{HCl} / \mathrm{CH}_{3} \mathrm{COOH}$ were not efficient and produced mixtures with low amounts of compound 4 difficult to separate by chromatography. Elimination of $\mathrm{HI}$ with DBU in toluene at $70{ }^{\circ} \mathrm{C}$ for $3 \mathrm{~h}$ gave the olefin 5 in $92 \%$ yield.

Compound 4 was entirely transformed, as confirmed by the disappearance of the CHI signal in ${ }^{1} \mathrm{H}$ NMR at $2.75 \mathrm{ppm}$. The reduction of olefin 5 was performed in methanol with hydrogen in the presence of Pd-C and gave product 6 in $83 \%$ yield after chromatography and crystallization in methanol. NMR spectra showed the high chiral purity of the sample. No $\alpha$ anomer was observed after the crystallization process. So we can confirm the high chiral purity of the sample. In a last step, Zemplen deprotection of $\mathbf{6}$ gave the fully deprotected $\mathbf{F}_{2} \mathbf{H}_{\mathbf{9}} \mathbf{\beta M}$ in good yield after chromatography.

\section{Physicochemical characterization of surfactants}

The synthesis and the use of new surfactants for MP stabilization and crystallization should be accompanied by the 
characterization of micelle behavior in solution (in particular CMC, micelle size and shape, and homogeneity) and MP stability studies in the presence of these novel surfactants.

The two novel fluorosurfactants, $\mathbf{F}_{2} \mathbf{H}_{9} \boldsymbol{\beta} \mathbf{M}$ and $\mathbf{F}_{\mathbf{4}} \mathbf{H}_{5} \boldsymbol{\beta M}$, were fully soluble in water (up to $10 \% \mathrm{w} / \mathrm{v}$ ) for further biophysical and biostructural studies in solution.

Micellization thermodynamics. ST measurements were performed to evaluate surface activities and micellization thermodynamics of $\mathbf{F}_{2} \mathbf{H}_{\mathbf{9}} \mathbf{\beta} \mathbf{M}$ and $\mathbf{F}_{\mathbf{4}} \mathbf{H}_{\mathbf{5}} \boldsymbol{\beta} \mathbf{M}$ and compared with those of $\mathbf{H}_{\mathbf{1 2}} \boldsymbol{\beta M}$ and $\mathrm{F}_{6} \mathrm{H}_{2} \beta \mathrm{M}$ in aqueous solution. Fig. 1 depicts the surface tension $(\gamma)$ measurements versus concentration for each surfactant in water at $18{ }^{\circ} \mathrm{C}$. The surface tension initially decreased with increasing concentration of surfactants, suggesting that the surfactant molecules adsorbed at the air/water interface, reaching a break point when micelles form, which was taken as the CMC.

The values of the CMC, surface tension at the CMC $\left(\gamma_{\mathrm{CMC}}\right)$, maximum surface excess concentration $\left(\Gamma_{\max }\right)$, minimum occupied area per molecule $\left(A_{\min }\right)$, free energy of micellization $\left(\Delta G_{\text {mic }}^{\circ}\right)$, and free energy of adsorption $\left(\Delta G_{\text {ads }}^{\circ}\right)$ of the fluorinated surfactants extracted from this graph are listed in Table 1, along with the data of highly fluorinated maltosides and different alkyl maltosides. The CMCs corresponding to the break point of the surface tension versus surfactant concentration are presented in Table 2.

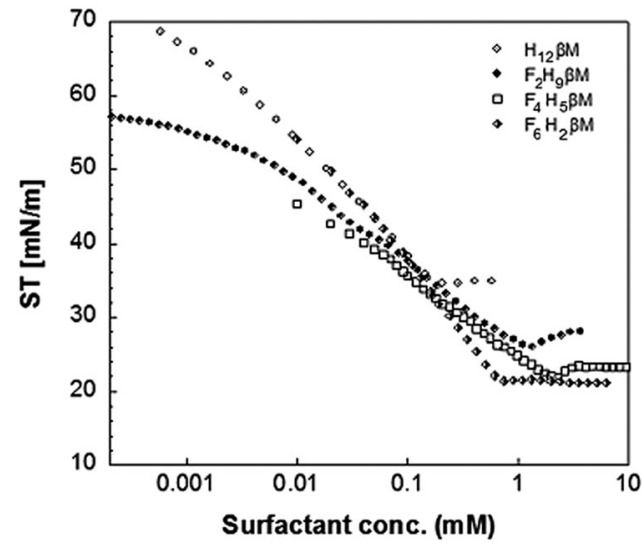

Fig. 1 Surface tension of $\mathbf{F}_{2} \mathrm{H}_{9} \boldsymbol{\beta} \mathbf{M}, \mathbf{F}_{\mathbf{4}} \mathbf{H}_{5} \boldsymbol{\beta} \mathbf{M}, \mathrm{F}_{6} \mathrm{H}_{2} \beta \mathrm{M}$, and $\mathbf{H}_{\mathbf{1 2}} \boldsymbol{\beta} \mathbf{M}$ as a function of their concentration.
As expected, the value of the surface tension at the CMC $\left(\gamma_{\mathrm{CMC}}\right)$ decreases when the length of the fluorinated segment increases. In agreement with the literature, ${ }^{38,44}$ the fluorinated maltoside-derived surfactants $\mathrm{F}_{n} \mathrm{H}_{m} \beta \mathrm{M}$ have a higher tendency to form aggregates than their analogues $\mathrm{H}_{m^{\prime}} \beta \mathrm{M}\left(m^{\prime}=n+m\right)$ with the same number of carbon atoms. In particular, the eight carbons of the partly fluorinated chain of $\mathrm{F}_{6} \mathrm{H}_{2} \beta \mathrm{M}$ (or the nine carbons of $\mathrm{F}_{6} \mathrm{H}_{3} \beta \mathrm{M}$ ) have the same hydrophobic contribution as the eleven carbons of the aliphatic chain of $\mathrm{H}_{11} \beta \mathrm{M}$ (or the twelve carbons of $\mathbf{H}_{\mathbf{1 2}} \boldsymbol{\beta M}$ ). This contribution for the highly fluorinated surfactants is in agreement with the $1 \mathrm{CF}_{2} \approx 1.5 \mathrm{CH}_{2}$ rule. By contrast, for the fluorinated surfactants $\mathbf{F}_{2} \mathbf{H}_{\mathbf{9}} \mathbf{\beta M}$ and $\mathbf{F}_{4} \mathbf{H}_{5} \boldsymbol{\beta M}$, this rule is not reflected in the measured values. While the CMC of a highly fluorinated chain $\left(\mathrm{F}_{6} \mathrm{H}_{2} \beta \mathrm{M}\right)$ is close to the CMC of an $\mathrm{H}_{11}$ chain, the CMCs of the partly fluorinated chains are far from the values expected by this rule (i.e., for $\mathrm{H}_{12}$ and $\mathrm{H}_{11}$ chains, respectively). The CMCs of $\mathbf{F}_{\mathbf{4}} \mathbf{H}_{5} \mathbf{\beta M}(2.16 \mathrm{mM})$ and $\mathbf{F}_{2} \mathbf{H}_{9} \boldsymbol{\beta M}(1.14 \mathrm{mM})$ correspond approximately to that of $\mathrm{H}_{10} \beta \mathrm{M}$ $(1.8 \mathrm{mM})$. Hence, it appears that the shorter the length of the fluorinated segment is, the less will be the 'hydrophobic' contribution of the fluorinated carbons. Thus, if we consider that the hydrophobic contribution of $\mathrm{CH}_{2}$ is constant for $\mathrm{H}_{10} \beta \mathbf{M}, \mathbf{F}_{\mathbf{4}} \mathbf{H}_{\mathbf{5}} \boldsymbol{\beta} \mathbf{M}$, and $\mathbf{F}_{\mathbf{2}} \mathbf{H}_{\mathbf{9}} \boldsymbol{\beta} \mathbf{M}$, we deduce that for $\mathbf{F}_{\mathbf{4}} \mathbf{H}_{\mathbf{5}} \boldsymbol{\beta} \mathbf{M}$, $1 \mathrm{CF}_{2} \approx 1.25 \mathrm{CH}_{2}$ and for $\mathbf{F}_{2} \mathbf{H}_{\mathbf{9}} \mathbf{\beta M}, 1 \mathrm{CF}_{2} \approx 0.5 \mathrm{CH}_{2}$. Therefore, for a short fluorinated tip at the end of the aliphatic chain, the hydrophobic contribution of a $\mathrm{CF}_{2}$ becomes lower than that of a $\mathrm{CH}_{2}$.

This reduced, context-dependent hydrophobic contribution of a $\mathrm{CF}_{2}$ group residing in a short fluorinated tip becomes even more obvious upon comparison with nonfluorinated detergents in terms of the thermodynamics of micellization. In agreement with literature reports, ${ }^{38}$ we observe that $\Delta G_{\text {mic }}^{\circ}$ of $\mathrm{F}_{6} \mathrm{H}_{3} \beta \mathrm{M}\left(-30.3 \mathrm{~kJ} \mathrm{~mol}^{-1}\right)$ is more exergonic than that of $\mathrm{H}_{9} \beta \mathrm{M}$ $\left(-22.6 \mathrm{~kJ} \mathrm{~mol}^{-1}\right)$. By contrast, however, $\mathbf{F}_{\mathbf{2}} \mathbf{H}_{\mathbf{9}} \mathbf{\beta} \mathbf{M}\left(-26.0 \mathrm{~kJ} \mathrm{~mol}^{-1}\right)$ has a reduced affinity for micellization compared with its

Table 2 CMC from the different techniques

\begin{tabular}{|c|c|c|c|c|c|}
\hline Surfactant & $\mathrm{ST}(\mathrm{mM})$ & ${ }^{19} \mathrm{~F}$ NMR $(\mathrm{mM})$ & ITC (mM) & AUC (mM) & SAXS $(\mathrm{mM})$ \\
\hline $\mathbf{H}_{9} \boldsymbol{\beta} \mathbf{M}$ & 1.14 & 1.13 & 1.19 & 2.1 & 1.24 \\
\hline $\mathbf{F}_{4} \mathbf{H}_{5} \beta M$ & 2.16 & 1.91 & 2.15 & 2.8 & 2.43 \\
\hline $\mathrm{F}_{6} \mathrm{H}_{2} \beta \mathrm{M}$ & 0.71 & $0.9^{20}$ & $0.7^{20}$ & 2.5 & 0.90 \\
\hline
\end{tabular}

Table 1 Surface tension parameters (* values from the Anatrace catalog; n.a. not available in the literature)

Calculated hydrophobic

contribution $\quad \mathrm{CMC} \quad \gamma_{\mathrm{CMC}} \quad \Gamma_{\max } \quad \pi_{\mathrm{CMC}}$

$A_{\text {min }}$

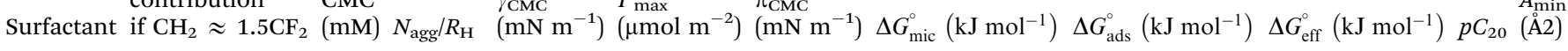

\begin{tabular}{|c|c|c|c|c|c|c|c|c|c|c|}
\hline $\mathrm{H}_{8} \beta \mathrm{M}$ & $8 \mathrm{C}$ & $19.5^{*}$ & $55 / 2.1^{5}$ & n.a. & n.a. & n.a. & -19.6 & n.a & n.a. & n.a. n.a. \\
\hline $\mathrm{H}_{9} \beta \mathrm{M}$ & $9 \mathrm{C}$ & $6^{*}$ & $66 / 2.5^{5}$ & n.a. & n.a. & n.a. & -22.6 & n.a. & n.a. & n.a. n.a. \\
\hline $\mathrm{H}_{11} \beta \mathrm{M}$ & $11 \mathrm{C}$ & $0.59^{*}$ & $105 / 3.1^{5}$ & n.a. & n.a. & n.a. & -28.4 & n.a. & n.a. & n.a. n.a. \\
\hline $\mathrm{H}_{12} \boldsymbol{\beta M}$ & $12 \mathrm{C}$ & 0.17 & $125 / 3.4^{5}$ & 34.7 & 2.72 & 37.3 & -30.7 & -44.4 & -13.7 & $1.87 \quad 61$ \\
\hline$F_{4} H_{5} \beta M$ & $11 \mathrm{C}$ & 2.16 & $50 / 4.6$ & 22 & 1.87 & 50 & -24.5 & -51.3 & -26.8 & 2.8189 \\
\hline $\mathrm{F}_{6} \mathrm{H}_{2} \beta \mathrm{M}$ & $11 \mathrm{C}$ & 0.71 & $800 / 15.6$ & 21.2 & 3.52 & 50.8 & -27.2 & -41.6 & -14.4 & $1.84 \quad 47$ \\
\hline $\mathrm{F}_{6} \mathrm{H}_{3} \beta \mathrm{M}$ & $12 \mathrm{C}$ & 0.2 & n.a. & 17.5 & 4.37 & 54.5 & -30.3 & -42.8 & -12.5 & n.a. 38 \\
\hline
\end{tabular}


hydrocarbon counterpart $\mathrm{H}_{11} \beta \mathrm{M}\left(-28.4 \mathrm{~kJ} \mathrm{~mol}^{-1}\right)$. This is not the case for $\mathbf{F}_{4} \mathbf{H}_{5} \mathbf{\beta} \mathbf{M}\left(-24.5 \mathrm{~kJ} \mathrm{~mol}^{-1}\right)$, which has a greater tendency to micellize than its hydrocarbon counterpart $\mathrm{H}_{9} \beta \mathrm{M}$ $\left(-22.6 \mathrm{~kJ} \mathrm{~mol}^{-1}\right)$. Thus, the usual increase in hydrophobic contribution conferred by fluorine atoms becomes marginal for very low fluorinated derivatives, and a small perfluoroethyl tip even seems to disturb the formation of micelles, presumably because of packing constraints in the micelle core. A good measure of the adsorption efficiency of a surfactant is its concentration required to produce a $20 \mathrm{mN} \mathrm{m}^{-1}$ reduction in surface tension, ${ }^{45}$ as expressed by the negative logarithm of this concentration, $p C_{20}$. The larger the $p C_{20}$ value is, the more efficiently the surfactant will reduce the surface tension. As shown in Table 1, $p C_{20}$ values for the fluorinated surfactants were observed to increase for low fluorinated surfactants compared with fluorinated $\mathrm{F}_{6} \mathrm{H}_{2} \beta \mathrm{M}$. This result indicates that low fluorinated surfactants have a higher tendency to adsorb at the interface.

The Gibbs free energy change for adsorption $\left(\Delta G_{\text {ads }}^{\circ}\right)$ was calculated using the following equation:

$$
\Delta G_{\mathrm{ads}}^{\circ}=2.3 R T(\log \mathrm{CMC} / M-\log 55.5)-\Pi_{\mathrm{CMC}} / \Gamma_{\max }
$$

The $\Delta G_{\text {ads }}^{\circ}$ values are more negative than their corresponding $\Delta G_{\text {mic }}^{\circ}$ values, indicating that the transfer of the surfactant from the air/water interface to the micelle is unfavorable. The difference between the $\Delta G_{\text {ads }}^{\circ}$ and $\Delta G_{\text {mic }}^{\circ}$ values is called the effective Gibbs free energy change $\Delta G_{\text {eff }}^{\circ}{ }^{46}$ It was observed (Table 1) that $\Delta G_{\text {eff }}^{\circ}$ is significantly more negative when the degree of fluorination in the hemifluorinated chain is low, indicating that micellization is less favorable as compared with surface adsorption.

The surface excess concentration at surface saturation $\left(\Gamma_{\max }\right)$ is another useful measure of the effectiveness of surfactant adsorption at the air/water interface, as it is the maximum value that adsorption can attain. ${ }^{47}$ For instance, straight chains favor close, effective packing, whereas branched chains experience steric hindrance at the interface. The larger the $\Gamma_{\max }$ is, the more tightly is the surfactant packed at the interface. We found that the sparingly fluorinated surfactants have a lower surface excess than the highly fluorinated surfactants $\mathrm{F}_{6} \mathrm{H}_{2} \beta \mathrm{M}$ and $\mathrm{F}_{6} \mathrm{H}_{3} \beta \mathrm{M}$ and even than the non-fluorinated $\mathbf{H}_{\mathbf{1 2}} \boldsymbol{\beta} \mathbf{M}$. However, fluorinated surfactants have a very strong ability to form tightly packed and organized films at the air/water interface ${ }^{38}$ and, thus, are excellent emulsifying and foaming agents. This general rule is confirmed by comparing the excess surface of $\mathrm{F}_{6} \mathrm{H}_{2} \beta \mathrm{M}$ and $\mathrm{F}_{6} \mathrm{H}_{3} \beta \mathrm{M}$ with that of $\mathbf{H}_{\mathbf{1 2}} \boldsymbol{\beta M}$. Therefore, the air/water interface behavior of the novel fluorinated surfactants presents an anomaly, as failure to tightly pack at the air/water interface is usually related to the presence of bulky, branched, or multiple aliphatic chains.

The area occupied per surfactant molecule at the air/water interface can be obtained from the value of the excess surface since $A_{\min }=10^{16} / N_{\mathrm{a}} \Gamma_{\max }$. A greater efficacy of adsorption at the interface means that the area occupied by the surfactant molecule is smaller.
In the case of $\mathbf{F}_{4} \mathbf{H}_{5} \boldsymbol{\beta} \mathbf{M}$ and $\mathbf{F}_{2} \mathbf{H}_{9} \boldsymbol{\beta} \mathbf{M}$, we observed a strong, that is, two-fold increase in surface area compared with the highly fluorinated surfactants $\mathrm{F}_{6} \mathrm{H}_{2} \beta \mathrm{M}$ and $\mathrm{F}_{6} \mathrm{H}_{3} \beta \mathrm{M}$. Sadtler et $a .^{48}$ have found similar behavior in a series of partially fluorinated surfactants with a dimorpholinophosphate head group. They observed an unexplained break when the number of fluorinated carbon atoms is lower than eight. We believe that the increase in the area occupied by the low fluorinated chain is related to a kink in the hydrophobic tail, that is bending between the fluorinated tip and the hydrogenated segment of the aliphatic chain. This bending can also affect their adsorption efficiency at the air/water interface and the mode of micellar aggregation.

Micellization behavior. ${ }^{19} \mathrm{~F}$ NMR chemical shifts are known to be sensitive to the surrounding environment. Therefore, ${ }^{19} \mathrm{~F}$ NMR is an excellent tool to study the aggregation behavior of fluorinated surfactants..$^{20,49,50}$ It offers the advantage of independently observing the behavior of partly fluorinated compounds because there is no overlap with the ${ }^{1} \mathrm{H}$ signals of hydrocarbon components. It is well known that the chemical shift of fluorine nuclei shows an upfield movement upon micellization. ${ }^{20,51}$ The peak of the $\mathrm{CF}_{3}$ group in the fluorocarbon chain is the strongest, and its chemical shift usually is the most sensitive to micellization. Above their CMC, surfactant molecules are present in both monomeric and micellar states. As a consequence, the observed chemical shift $\left(\delta_{\text {obs }}\right)$ is a weighted average of the monomer shift $\left(\delta_{\text {mon }}\right)$ and the micellar shift $\left(\delta_{\text {mic }}\right)$ :

$$
\delta_{\text {obs }}=p \delta_{\text {mon }}+(1-p) \delta_{\text {mic }}
$$

where $p$ is the fraction of the monomer.

To obtain the CMC, the concentration of monomers above the CMC is assumed to equal the CMC value irrespective of the total surfactant concentration $(c) .{ }^{52}$

$$
p=\mathrm{CMC} / c
$$

Substituting $p$ in eqn (1), we obtain:

$$
\begin{gathered}
\delta_{\text {obs }}=(\mathrm{CMC} / c) \delta_{\text {mon }}+(1-\mathrm{CMC} / c) \delta_{\text {mic }} \\
\delta_{\text {obs }}=\delta_{\text {mic }}+\left(\delta_{\text {mon }}-\delta_{\text {mic }}\right) \mathrm{CMC} / c
\end{gathered}
$$

At concentrations above the CMC, eqn (3) predicts that $\delta$ depends linearly on the inverse concentration. The variation of the chemical shifts of the $\mathrm{CF}_{3}$ group as a function of surfactant concentration can be conveniently expressed relative to the monomer shift $\delta_{\text {mon }}$ by using the difference $\Delta \delta$ between the chemical shift observed at a given concentration and that measured below the CMC, that is:

$$
\Delta \delta=\delta_{\text {obs }}-\delta_{\text {mon }}
$$

To determine the CMC from NMR data according to eqn (3) and (4), $\Delta \delta$ is plotted versus the reciprocal concentration (Fig. 2). In both high- and low-concentration ranges, the chemical shift data can then be linearly fitted by least-squares analysis. The intersection of the sloping and horizontal lines provides a CMC value of $1.13 \mathrm{mM}$ for $\mathbf{F}_{\mathbf{2}} \mathbf{H}_{\mathbf{9}} \boldsymbol{\beta} \mathbf{M}$, in good agreement with the 


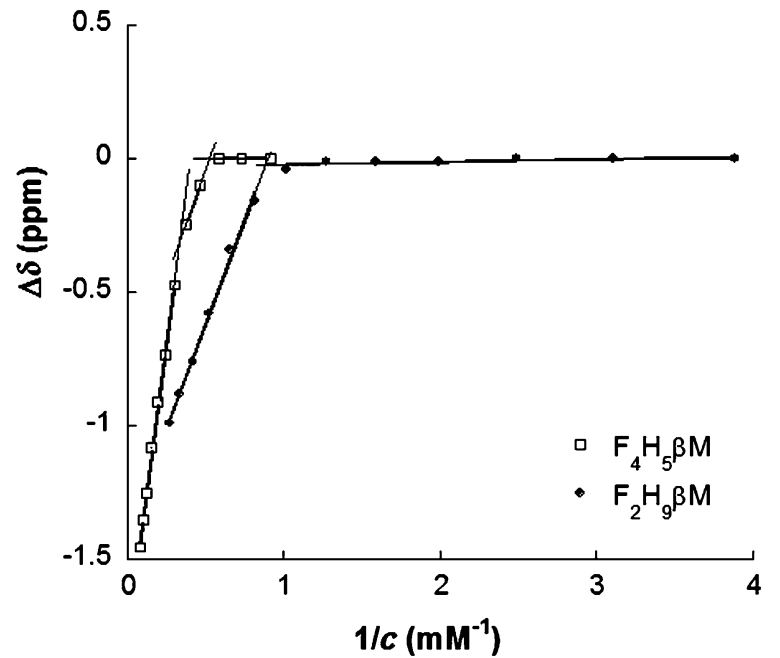

Fig. $2{ }^{19} \mathrm{~F}$ NMR chemical shift changes $(\Delta \delta)$ of the $\mathrm{CF}_{3}$ group of $\mathbf{F}_{2} \mathrm{H}_{9} \boldsymbol{\beta} \mathbf{M}$ and $\mathrm{F}_{4} \mathrm{H}_{5} \boldsymbol{\beta} \mathrm{M}$ versus the reciprocal value of their concentration in water.

values obtained by surface tension $(1.14 \mathrm{mM})$. There is only a single break point, indicating that there is no premicelle formation.

By contrast, ${ }^{19} \mathrm{~F}$ chemical shifts of $\mathrm{CF}_{3}$ in the fluorocarbon chain of $\mathrm{F}_{4} \mathrm{H}_{5}$ Malt as a function of surfactant concentration reveal two break points at $1.9 \mathrm{mM}$ and $3.0 \mathrm{mM}$, indicating that a premicellization process takes place before the formation of "mature" micelles. This particular behavior has already been described for fluorinated surfactants dissolved in ionic liquids. ${ }^{53,54}$ Consistent with NMR titrations, demicellization isotherms derived from high-sensitivity ITC revealed a well-defined micellization behavior for $\mathbf{F}_{2} \mathbf{H}_{9} \boldsymbol{\beta} \mathbf{M}$ (Fig. 3A and C).

These isotherms displayed a single sigmoid transition from the submicellar to the micellar concentration range at $1.19 \mathrm{mM}$ and, hence, were straightforward to analyze, yielding essentially the same CMC value as obtained from NMR and ST.

By contrast, for $\mathbf{F}_{4} \mathbf{H}_{5} \boldsymbol{\beta} \mathbf{M}$, there was a pronounced, reproducible dip within the transition region of the isotherm (Fig. 3B and D). A first maximum appears at a surfactant concentration of $2.15 \mathrm{mM}$ and a second one at $2.77 \mathrm{mM}$, suggesting that there is some structural rearrangement with increasing surfactant concentration. Again, these concentration values agreed with those found using ST and NMR (Table 2).

Micelle size and morphology. Sedimentation velocity (SV) AUC is particularly suitable to assess sample homogeneity, and determine the association state of complexes, and may provide indications on the general shape of the macromolecules. The superposition of sedimentation velocity profiles acquired for every $\sim 20 \mathrm{~min}$, for $\mathbf{F}_{2} \mathbf{H}_{9} \boldsymbol{\beta} \mathbf{M}, \mathbf{F}_{4} \mathbf{H}_{5} \boldsymbol{\beta} \mathbf{M}$, and $\mathrm{F}_{6} \mathrm{H}_{2} \beta \mathbf{M}$ at $2 \mathrm{~g} \mathrm{~L}^{-1}$, shows a fast boundary corresponding to micelles moving at significantly different velocities, depending on the surfactant type, and a slow boundary (Fig. S1A-F, ESI $\dagger$ ). At the lowest concentrations of $\mathbf{F}_{2} \mathbf{H}_{9} \boldsymbol{\beta M}$ and $\mathrm{F}_{6} \mathrm{H}_{2} \beta \mathrm{M}$, a slow boundary moved at $(0.3 \pm 0.1) \mathrm{S}$, which may correspond to the monomer below the CMC. At higher concentrations, by contrast, poorly characterized sedimentation detected at larger $s$-values
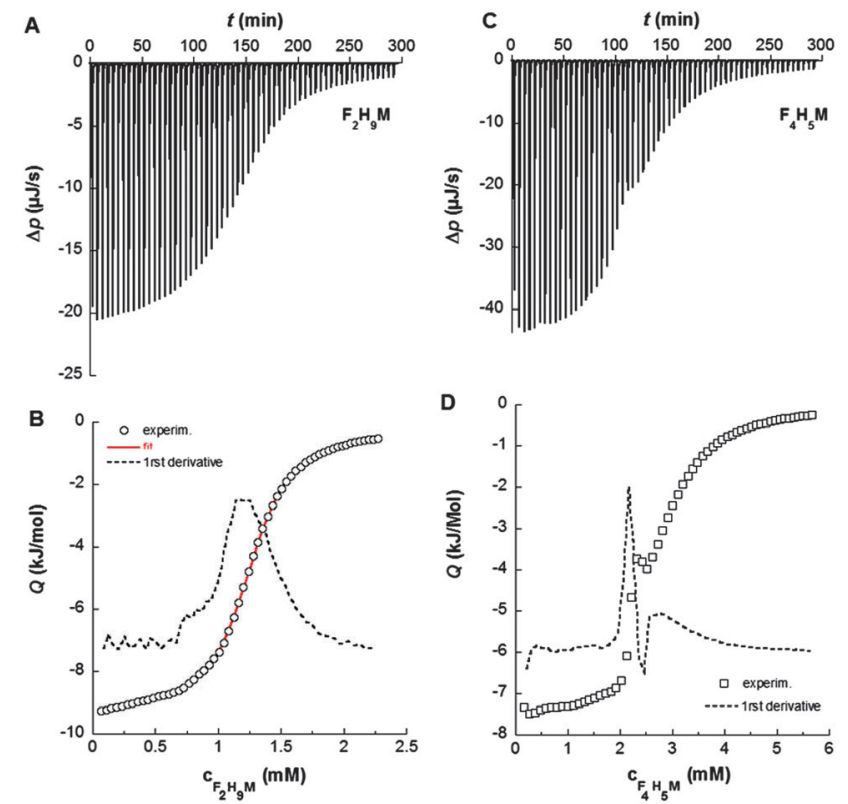

Fig. 3 ITC demicellization experiments at $21^{\circ} \mathrm{C}$. (A) Thermogram displaying differential heating power, $\Delta p$, against time, $t$, for a titration of $12 \mathrm{mM}$ $\mathbf{F}_{2} \mathrm{H}_{9} \boldsymbol{\beta} \mathbf{M}$ into water. (B) Corresponding isotherm (circles) showing molar reaction heats, $Q$, against $F_{2} H_{9} \beta M$ concentration with the first derivative (dashed line) and a sigmoidal fit (red solid line). (C) Thermogram for a titration of $30 \mathrm{mM} \mathrm{F}_{4} \mathrm{H}_{5} \mathbf{\beta M}$ into water. (D) Corresponding isotherm (squares) with the first derivative (dashed line).

(i.e., (0.7-0.9) S above $2 \mathrm{~g} \mathrm{~L}^{-1}$ for $\mathbf{F}_{2} \mathbf{H}_{\mathbf{9}} \mathbf{\beta M}$ and (1.2-1.7) $\mathrm{S}$ above $4 \mathrm{~g} \mathrm{~L}^{-1}$ for $\left.\mathbf{F}_{4} \mathbf{H}_{5} \boldsymbol{\beta M}\right)$ may correspond to small aggregates of about 10 molecules. The corresponding molar concentrations, measured from fringe shift numbers, were below $0.5 \mathrm{mM}$. The fast boundary corresponded to surfactant micelles. $\mathbf{F}_{2} \mathbf{H}_{\mathbf{9}} \mathbf{\beta M}$ and $\mathbf{F}_{4} \mathbf{H}_{5} \boldsymbol{\beta} \mathbf{M}$ sedimented at $4 \mathrm{~S}$ and $(6.8 \pm 0.1) \mathrm{S}$, respectively, as homogeneous or rather homogeneous species, and $\mathrm{F}_{6} \mathrm{H}_{2} \beta \mathrm{M}$ in the range of (10-30) $\mathrm{S}$ as heterogeneous species. From the linear fit of the plot of the total micelle signal, given in fringe shifts $(\Delta J)$, versus the surfactant concentration (Fig. $4 \mathrm{~A}$ ), we derived values for the $\mathrm{CMC}$ and the refractive index increment; from absorbance data measured at $280 \mathrm{~nm}$ (not shown), we also obtained the extinction coefficient of the surfactants (Table S1, $\mathrm{ESI}+$ ). The values of CMC are significantly larger when compared to those derived from other techniques, because the transition is not clearly defined and had to be extrapolated from measurements at concentrations above $2 \mathrm{~g} \mathrm{~L}^{-1}$. For $\mathbf{F}_{4} \mathbf{H}_{5} \boldsymbol{\beta} \mathbf{M}$, the $s$-value of the micelles does not significantly change with concentration in the investigated range. For $\mathbf{F}_{2} \mathbf{H}_{9} \mathbf{\beta M}$, it slightly decreases with increasing concentration, which indicates repulsive micellemicelle interactions (Fig. 4B). The derived $k_{s}{ }^{\prime}$-values of -17 is larger but in the range of values expected from excluded volume interactions ( 8 times the swollen specific volume ${ }^{31}$ ). The extrapolation to infinite micelle dilution gives $s_{0}$ values of $4.2 \mathrm{~S}$ and $6.8 \mathrm{~S}$ for $\mathbf{F}_{2} \mathbf{H}_{9} \boldsymbol{\beta} \mathbf{M}$ and $\mathbf{F}_{4} \mathbf{H}_{5} \boldsymbol{\beta} \mathbf{M}$, respectively. For $\mathrm{F}_{6} \mathrm{H}_{2} \beta \mathrm{M}$, the sedimentation coefficient of the micelle increases with concentration, indicating larger micelles, reaching an $s_{\max }$-value of $28 \mathrm{~S}$. When combining these $s_{0}$ and $s_{\max }$ with the hydrodynamic radius measured by DLS (Table 3), we derived aggregation 

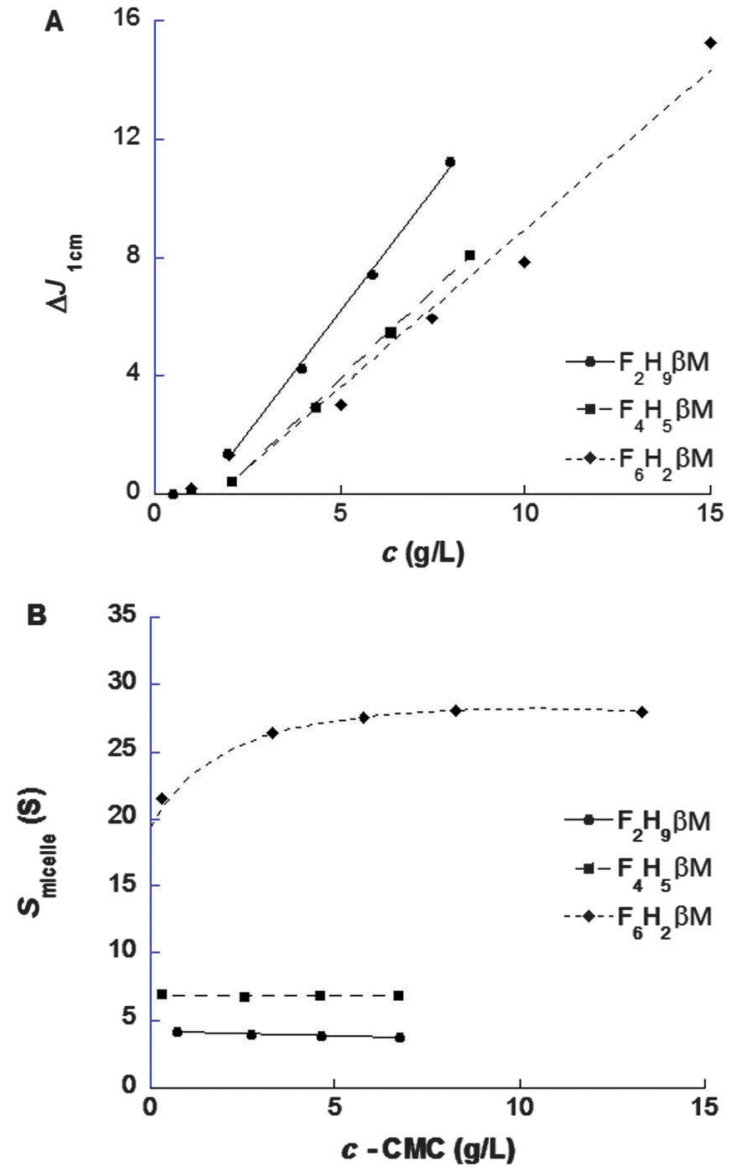

Fig. 4 Sedimentation velocity experiments. Plots of the micelle signal, in fringe shifts, versus surfactant concentration (A), and of the mean $s$ for the micelle versus micelle concentration (B). The lines in (A) and (B) are linear fits for concentrations $\geq 2 \mathrm{~g} \mathrm{~L}^{-1}$, except for $\mathrm{F}_{6} \mathrm{H}_{2} \beta \mathrm{M}$ in (B), where it gives a guide to the eye.

Table 3 Structural parameters of surfactant micelles

\begin{tabular}{lll}
\hline Surfactant & $\begin{array}{l}D_{0}\left(\mu^{2} \mathrm{~s}^{-1}\right) / \\
R_{\mathrm{H}}(\mathrm{nm}) \text { from DLS }\end{array}$ & $\begin{array}{l}R_{\mathrm{G}}(\mathrm{nm}) / D_{\max }(\mathrm{nm}) / \\
N_{\mathrm{agg}} \text { from SAXS }\end{array}$ \\
\hline $\mathbf{H}_{\mathbf{1 2}} \boldsymbol{\beta M}$ & $61.9 / 3.6$ & $3.2 / 8.0 / 125^{a}$ \\
$\mathbf{F}_{2} \mathbf{H}_{9} \boldsymbol{\beta M}$ & $81.9 / 2.7$ & $2.5 / 7.6 / \sim 65$ \\
$\mathbf{F}_{\mathbf{4}} \mathbf{H}_{5} \boldsymbol{\beta M}$ & $47.6 / 4.6$ & $3.2 / 10.8 / \sim 50$ \\
$\mathrm{~F}_{6} \mathrm{H}_{2} \beta \mathbf{M}$ & $14.1 / 15.6$ & $158 / 57 />800$ \\
${ }^{a}$ From ref. 12. & & \\
\end{tabular}

numbers of 87,154 , and 1750 , and frictional ratios of 1.1 , 1.6, and 2.4, for $\mathbf{F}_{2} \mathbf{H}_{9} \boldsymbol{\beta} \mathbf{M}, \mathbf{F}_{4} \mathbf{H}_{5} \boldsymbol{\beta} \mathbf{M}$, and $\mathrm{F}_{6} \mathrm{H}_{2} \beta \mathrm{M}$, respectively (Table S1, ESI $\dagger$ ). This indicates that $\mathbf{F}_{2} \mathbf{H}_{\mathbf{9}} \mathbf{\beta} \mathbf{M}$ micelles are small, globular, and compact; $\mathbf{F}_{\mathbf{4}} \mathbf{H}_{\mathbf{5}} \mathbf{\beta} \mathbf{M}$ micelles are larger and more anisotropic; $\mathrm{F}_{6} \mathrm{H}_{2} \beta \mathrm{M}$ forms very large micelles with a strongly anisotropic shape in the $\mathrm{mg} \mathrm{mL}^{-1}$ range, as observed previously by transmission electron microscopy. ${ }^{20}$ Analysis of $c(s)$ for $\mathbf{F}_{\mathbf{4}} \mathbf{H}_{\mathbf{5}} \boldsymbol{\beta} \mathbf{M}$ above $4 \mathrm{~g} \mathrm{~L}^{-1}$ reveals a small shoulder at $5 \mathrm{~S}$, the relevance of which is difficult to ascertain but which may indicate aggregates composed of $\sim 65$ surfactant monomers if one assumes a globular shape at a concentration of $\sim 0.3 \mathrm{mM}$ (or more monomers for an elongated shape).
Light and X-ray scattering are suitable techniques to characterize molecular and structural parameters of particles in solution such as the size and the molar mass and to derive lowresolution models. These techniques also allow the characterization of weak interactions between particles in solution (i.e., repulsion or attraction) to control the phase diagrams for crystallization. ${ }^{55-58}$ DLS experiments were performed on both fluorinated surfactants prior to SAXS in order to evaluate their dispersity (i.e., the presence of different kinds of aggregates) and micelle size. Concentration series for the three fluorosurfactants above their respective CMC (from ST) were measured to determine size distributions weighted by intensity or volume (Fig. S2, ESI $\dagger$ ) and micelle diffusion coefficients $\left(D_{t}\right)$ as functions of surfactant concentration. ${ }^{32}$ Although large aggregates $(>100 \mathrm{~nm})$ appeared in intensity-weighted size distributions for $\mathbf{F}_{2} \mathbf{H}_{\mathbf{9}} \mathbf{\beta M}$ (Fig. S2B, ESI $\dagger$ ) and $\mathbf{F}_{\mathbf{4}} \mathbf{H}_{5} \boldsymbol{\beta} \mathbf{M}$ (Fig. S2E, ESI $\dagger$ ), their contribution was negligible in volume-weighted distributions $(<1 \%)$. The hydrodynamic radius $\left(R_{\mathrm{H}}\right)$ of fluorosurfactant micelles obtained via the Stoke-Einstein equation was determined by extrapolation to zero concentration of $D_{t}=f(c-\mathrm{CMC}$ ) (Table 3$)$ of the major distribution peak to account for intermicellar interaction effects. $R_{\mathrm{H}}$ increases as the length of the fluorinated segment increases, although the total number of carbons (i.e., the chain length) decreases, in contrast to what is observed with alkyl chains. ${ }^{59,60}$ The micelle size of hemifluorinated surfactants is thus influenced by the length of the fluorinated segment. With a short fluorinated segment, micelles of $\mathbf{F}_{\mathbf{2}} \mathbf{H}_{\mathbf{9}} \boldsymbol{\beta} \mathbf{M}$ are smaller than $\mathbf{H}_{\mathbf{1 2}} \boldsymbol{\beta} \mathbf{M}$ micelles and behave like micelles of a hydrogenated surfactant with an alkyl chain having $\sim 10$ carbons, as it was observed above for CMC and micellization thermodynamics. In contrast to a long fluorinated chain and a linear maltoside headgroup, $\mathrm{F}_{6} \mathrm{H}_{2} \beta \mathrm{M}$ forms elongated micelles like $\mathrm{F}_{6} \mathrm{H}_{3} \beta \mathrm{M},{ }^{22}$ as expected from the packing parameter concept ${ }^{23}$ and recently described. ${ }^{20,32}$ For $\mathbf{F}_{4} \mathbf{H}_{5} \mathbf{\beta M}$, which is composed of half-hydrogenated and half-fluorinated segments, $R_{\mathrm{H}}$ is larger than for $\mathbf{H}_{\mathbf{1 2}} \boldsymbol{\beta} \mathbf{M}$ micelles, although the hydrophobic chain is shorter. We expected peculiar behavior because of the poor miscibility of fluorinated and hydrogenated segments, which may confer packing defects to micellar assemblies.

Complementary structural information on fluorosurfactant micelle assemblies in solution was obtained from SAXS experiments. Fig. 5A depicts SAXS curves for each fluorosurfactant at $10 \mathrm{~g} \mathrm{~L}^{-1}$ ( $c>$ CMC). SAXS curves at different concentrations between 2 and $40 \mathrm{~g} \mathrm{~L}^{-1}$, pair distribution functions, and forward scattering intensity for CMC determination are shown in Fig. S3 and S4 (ESI $\dagger$ ). For $\mathbf{F}_{2} \mathbf{H}_{9} \mathbf{\beta M}$ and $\mathrm{F}_{6} \mathrm{H}_{2} \beta \mathrm{M}$, the variation of forward intensity was linear with surfactant concentration; for $\mathbf{F}_{4} \mathbf{H}_{5} \boldsymbol{\beta M}$, by contrast, we observed a break in the slope, in line with the chemical shifts observed by NMR. CMC values obtained from the extrapolation of forward intensity as a function of total concentration for $\mathbf{F}_{2} \mathbf{H}_{9} \boldsymbol{\beta} \mathbf{M}$ and $\mathrm{F}_{6} \mathrm{H}_{2} \beta \mathbf{M}$ were found to be consistent with other techniques (ST, ITC, and ${ }^{19} \mathrm{~F}$ NMR). For $\mathbf{F}_{\mathbf{4}} \mathbf{H}_{\mathbf{5}} \boldsymbol{\beta} \mathbf{M}$, two CMC values were apparent, as observed by ${ }^{19} \mathrm{~F}$ NMR and ITC, which we attributed to premicellar rearrangement due to the particular structure of the hydrophobic chain. $\mathbf{F}_{2} \mathbf{H}_{9} \boldsymbol{\beta} \mathbf{M}$ and $\mathrm{F}_{6} \mathrm{H}_{2} \beta \mathrm{M}$ present a stable 
A
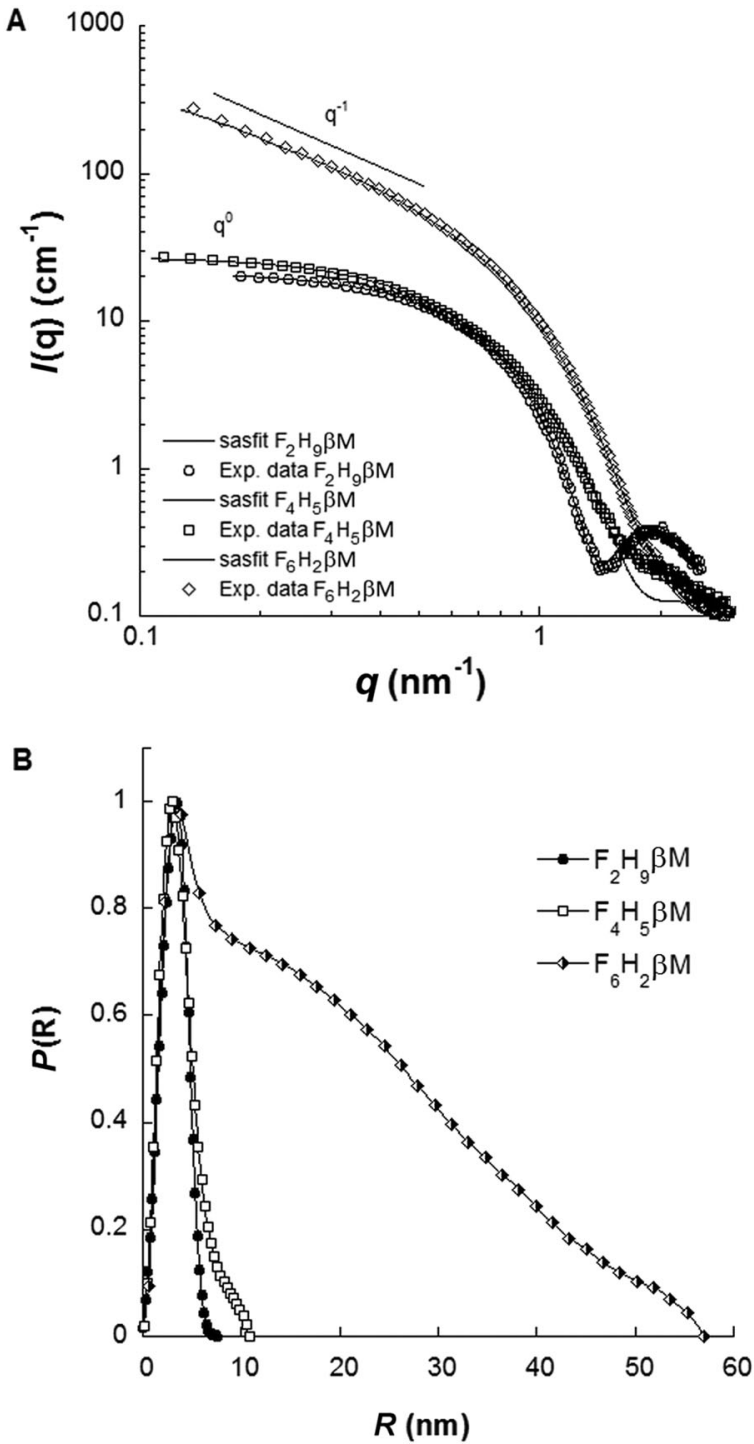

Fig. 5 (A) SAXS patterns in log-log representation and (B) pair distribution functions of $\mathbf{F}_{2} \mathrm{H}_{9} \boldsymbol{\beta} \mathbf{M}, \mathbf{F}_{4} \mathrm{H}_{5} \boldsymbol{\beta} \mathbf{M}$, and $\mathrm{F}_{6} \mathrm{H}_{2} \beta \mathrm{M}$ at $10 \mathrm{~g} \mathrm{~L}^{-1}$ in water.

shape from SAXS patterns at concentrations 6-8 times the CMC, as seen in the large $q$-range $\left(q>0.5 \mathrm{~nm}^{-1}\right)$ and repulsive interactions at high concentrations $\left(>20 \mathrm{~g} \mathrm{~L}^{-1}\right)$ (Fig. S3A and C, ESI $\dagger$ ). While $\mathbf{F}_{2} \mathbf{H}_{\mathbf{9}} \boldsymbol{\beta} \mathbf{M}$ forms small globular micelles with $N_{\text {agg }} \approx 65$ (i.e., $\left.M \approx(38000 \pm 1000) \mathrm{g} \mathrm{mol}^{-1}\right)$, as derived from the forward scattering intensity, $\mathrm{F}_{6} \mathrm{H}_{2} \beta \mathrm{M}$ forms elongated micelles with $N_{\text {agg }}>800$ (i.e., $\left.M \approx(550000 \pm 5000) \mathrm{g} \mathrm{mol}^{-1}\right)$, as obvious in the log-log representation. By contrast, $\mathbf{F}_{4} \mathbf{H}_{5} \boldsymbol{\beta M}$ micelles changed their size as a function of concentration (Fig. S3E, ESI $\dagger$ ) and experienced attractive interactions at high concentrations $\left(>20 \mathrm{~g} \mathrm{~L}^{-1}\right.$ ), as the forward intensity increased with concentration without a change in the form factor $\left(q>1 \mathrm{~nm}^{-1}\right)$. The molar mass and the aggregation number of $\mathbf{F}_{\mathbf{4}} \mathbf{H}_{5} \boldsymbol{\beta} \mathbf{M}$ micelles were determined from forward intensities to amount to $\sim 32000 \mathrm{~g} \mathrm{~mol}^{-1}$ and 50 molecules per micelle, respectively; this is less than the corresponding values of $\mathbf{F}_{2} \mathbf{H}_{\mathbf{9}} \boldsymbol{\beta} \mathbf{M}$ but as expected for this less hydrophobic chain. A thorough determination of micelle dimensions for the three fluorosurfactants was described in Dahani et al. ${ }^{32}$ The maximum distances in micelle assemblies $\left(D_{\max }\right)$ obtained from the pair distribution function $P(r)$ for the three fluorosurfactants (Fig. 5B) are in agreement with the hydrodynamic diameters obtained from DLS.

Finally, the SAXS form factors at $10 \mathrm{~g} \mathrm{~L}^{-1}$ were analyzed using least-squares models using the SASfit software package. ${ }^{61}$ Different models were used, either an ellipsoidal core-shell model for $\mathbf{F}_{2} \mathbf{H}_{9} \boldsymbol{\beta} \mathbf{M}$ and $\mathbf{F}_{4} \mathbf{H}_{5} \boldsymbol{\beta M}$ or a cylindrical core-shell model with an elliptical cross-section for $\mathrm{F}_{6} \mathrm{H}_{2} \beta \mathrm{M} . \rho_{\text {core }}, \rho_{\text {shell }}$, and $\rho_{\text {solv }}$ representing the scattering length densities of the core, the shell, and the solvent, respectively, are listed in Table S1 (ESI $\dagger$ ). $\mathbf{F}_{2} \mathbf{H}_{9} \boldsymbol{\beta M}$ is well fitted by an oblate ellipsoid with short and long axes estimated to be 1.3 and $2.5 \mathrm{~nm}$ and a shell thickness of $0.6 \mathrm{~nm}$. Our best model for $\mathbf{F}_{\mathbf{4}} \mathbf{H}_{5} \boldsymbol{\beta} \mathbf{M}$ was found to be a triaxial prolate ellipsoid with parameters $a, b, c$, and $t$ equal to 4.4, 1.7, 8.8 and $0.8 \mathrm{~nm}$, respectively. For $\mathrm{F}_{6} \mathrm{H}_{2} \beta \mathrm{M}$, the parameters for the cylindrical model are a core cross-section radius of $1.2 \mathrm{~nm}$, a shell thickness of $0.5 \mathrm{~nm}$, and a total length of $56 \mathrm{~nm}$. Aggregation numbers could be evaluated from these models by dividing the core volume by the hydrophobic chain volume. For $\mathbf{F}_{2} \mathbf{H}_{9} \boldsymbol{\beta} \mathbf{M}, \mathbf{F}_{4} \mathbf{H}_{5} \boldsymbol{\beta M}$, and $\mathrm{F}_{6} \mathrm{H}_{2} \beta \mathbf{M}$, we thus estimated aggregation numbers of $\sim 90,86$, and 511 , respectively, which are in good agreement with values from forward intensities, given that molar masses are typically subjected to $10-15 \%$ error from sample preparation and concentration estimation.

\section{Biochemical evaluation}

To test the biochemical usefulness of $\mathbf{F}_{2} \mathbf{H}_{\mathbf{9}} \boldsymbol{\beta} \mathbf{M}$ and $\mathbf{F}_{\mathbf{4}} \mathbf{H}_{5} \boldsymbol{\beta} \mathbf{M}$ and compare them to commercial $\mathrm{F}_{6} \mathrm{H}_{2} \beta \mathbf{M}$ and $\mathbf{H}_{\mathbf{1 2}} \boldsymbol{\beta M}$, their ability to keep MPs soluble and in their native form was tested by using bacteriorhodopsin (bR) as a model protein. bR is a lightdriven proton pump purified from the archaea Halobacterium. ${ }^{62}$ It is composed of seven transmembrane $\alpha$-helices and binds a covalent cofactor, a retinal molecule, whose visible absorption spectrum is very sensitive to its local environment. ${ }^{63}$ This makes it a convenient reporter of the native state of the protein: the trimeric protein in its native membranes reveals a visible absorption spectrum with a maximum at $\lambda_{\max }=570 \mathrm{~nm}$. When solubilized in detergent, the monomeric protein displays $\lambda_{\text {max }}=554 \mathrm{~nm}$; in both cases, the protein appears purple. When the protein denatures, the retinal is released, and $\lambda_{\text {max }}$ shifts to 400-380 nm, that is, the protein solution turns yellow. We have also reported that when the solubilized monomeric protein is transferred into a fluorinated surfactant, $\lambda_{\max }$ shifts to $615 \mathrm{~nm}$, giving a blue color to the protein-surfactant complex. ${ }^{30} \mathrm{bR}$ dimers and trimers, however, still appear purple in the same surfactants (i.e., $\lambda_{\max } \approx 570 \mathrm{~nm}$ ). Fig. 6 shows the results of sucrose density gradient experiments. This technique allows both surfactant exchange and evaluation of the colloidal homogeneity of the protein-surfactant complex. As expected from the small globular micelles formed by both surfactants, the sharp colored bands indicate homogeneous protein-surfactant complexes. Interestingly, we note that bR in $\mathbf{F}_{2} \mathbf{H}_{\mathbf{9}} \boldsymbol{\beta} \mathbf{M}$ migrated as a blue band, nearly at the same position as that in $\mathbf{H}_{\mathbf{1 2}} \boldsymbol{\beta} \mathbf{M}$. 


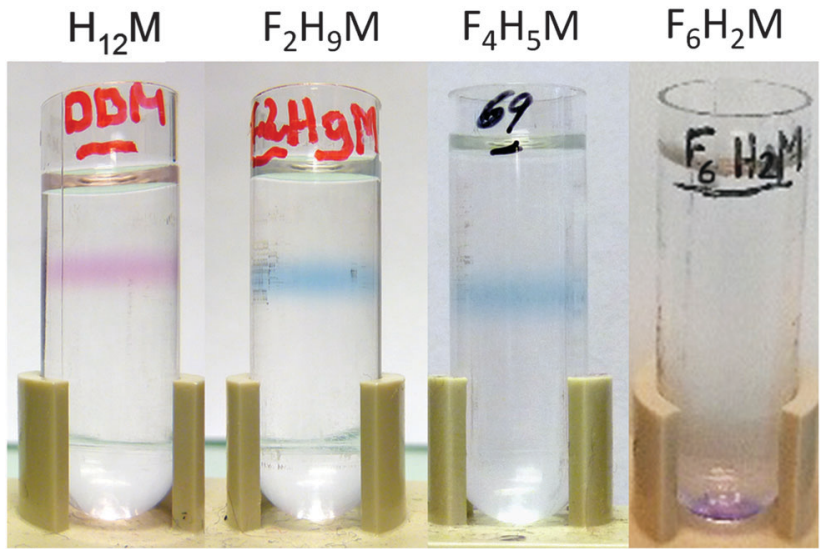

Fig. 6 Migration of bR in $10-30 \%$ sucrose gradients in the presence of $6 \mathrm{mM}$ of each surfactant (from left to right: $\mathrm{H}_{12} \boldsymbol{\beta} \mathbf{M}, \mathrm{F}_{2} \mathrm{H}_{9} \boldsymbol{\beta} \mathbf{M}, \mathrm{F}_{4} \mathrm{H}_{5} \boldsymbol{\beta}$, and $\mathrm{F}_{6} \mathrm{H}_{2} \beta M$ ). Gradients were centrifuged for $5 \mathrm{~h}$ at $200000 \mathrm{~g}$.

This is in agreement with the fact that $\mathbf{F}_{\mathbf{2}} \mathbf{H}_{\mathbf{9}} \boldsymbol{\beta} \mathbf{M}$, being less fluorinated, has a density closer to that of $\mathbf{H}_{\mathbf{1 2}} \boldsymbol{\beta} \mathbf{M}$. This blue band implied that bR was present as a monomer in this fluorinated surfactant, even though it migrated deeper into the gradient than monomeric bR in conventional detergents (see, e.g., ref. 30). When transferred into $\mathbf{F}_{\mathbf{4}} \mathbf{H}_{5} \boldsymbol{\beta} \mathbf{M}$, bR still gave rise to a blue band but migrated a bit deeper into the gradient, as expected for a protein-surfactant complex of higher density (note that the $\mathbf{F}_{2} \mathbf{H}_{9} \boldsymbol{\beta} \mathbf{M}$ and $\mathbf{F}_{4} \mathbf{H}_{5} \boldsymbol{\beta} \mathbf{M}$ gradients are not filled to the same extent). In stark contrast to our novel fluorosurfactants, $\mathrm{F}_{6} \mathrm{H}_{2} \beta \mathrm{M}$ led to the accumulation of bR from the pellet of the gradient, suggesting large protein-surfactant complexes. In another experiment, where the gradients were centrifuged more gently, the band appeared very broad and purple. This is in agreement with the fact that this surfactant forms large and heterogeneous micelles. Even though $\mathrm{F}_{6} \mathrm{H}_{2} \beta \mathrm{M}$ is a fluorinated surfactant, which normally yields blue $\mathrm{bR},{ }^{13,21}$ the pellet appeared purple. When resuspended, the spectrum of the protein-surfactant complex displayed $\lambda_{\text {max }} \approx 568 \mathrm{~nm}$, which suggests that the protein was not monomeric (Fig. 7C); it also diffused slightly, confirming the presence of large particles in the sample. As already observed for bR in $\mathrm{F}_{6}$-Monoglu, which also forms large protein-surfactant particles, the protein was very stable over a year and a half, albeit with an increase in diffusion suggesting further oligomerization or even aggregation of the protein. When transferred into $\mathbf{F}_{\mathbf{2}} \mathbf{H}_{\mathbf{9}} \mathbf{\beta} \mathbf{M}$, bR displayed $\lambda_{\text {max }}=610 \mathrm{~nm}$ (Fig. 7A). This species was stable over nearly a month but was slowly converted into a species with $\lambda_{\text {max }}=400 \mathrm{~nm}$, suggesting the denaturation of the protein. This was accompanied by the aggregation of the protein, as witnessed by the diffusion of the spectrum and by the conversion of the remaining $610 \mathrm{~nm}$ species into a species absorbing at $\sim 590 \mathrm{~nm}$, which probably resulted in the formation of highermolecular-weight species such as dimers, trimers, or higher. This species was, in turn, slowly converted into a $400 \mathrm{~nm}$ species, indicating that the protein continued to denature. When collected from the gradient, bR in $\mathbf{F}_{\mathbf{4}} \mathbf{H}_{\mathbf{5}} \mathbf{\beta} \mathbf{M}$ displayed $\lambda_{\max }=615 \mathrm{~nm}$ (Fig. 7B). After $\sim 5$ months (163 days) of incubation at $4{ }^{\circ} \mathrm{C}$ in the dark, the spectrum remained largely unchanged; hence the protein appeared very stable in this environment, showing no signs of denaturation or aggregation. Slight diffusion of the spectrum was observed after one year of incubation, but the same was observed for the control in the $\mathbf{H}_{\mathbf{1 2}} \boldsymbol{\beta} \mathbf{M}$ sample (Fig. 7D).
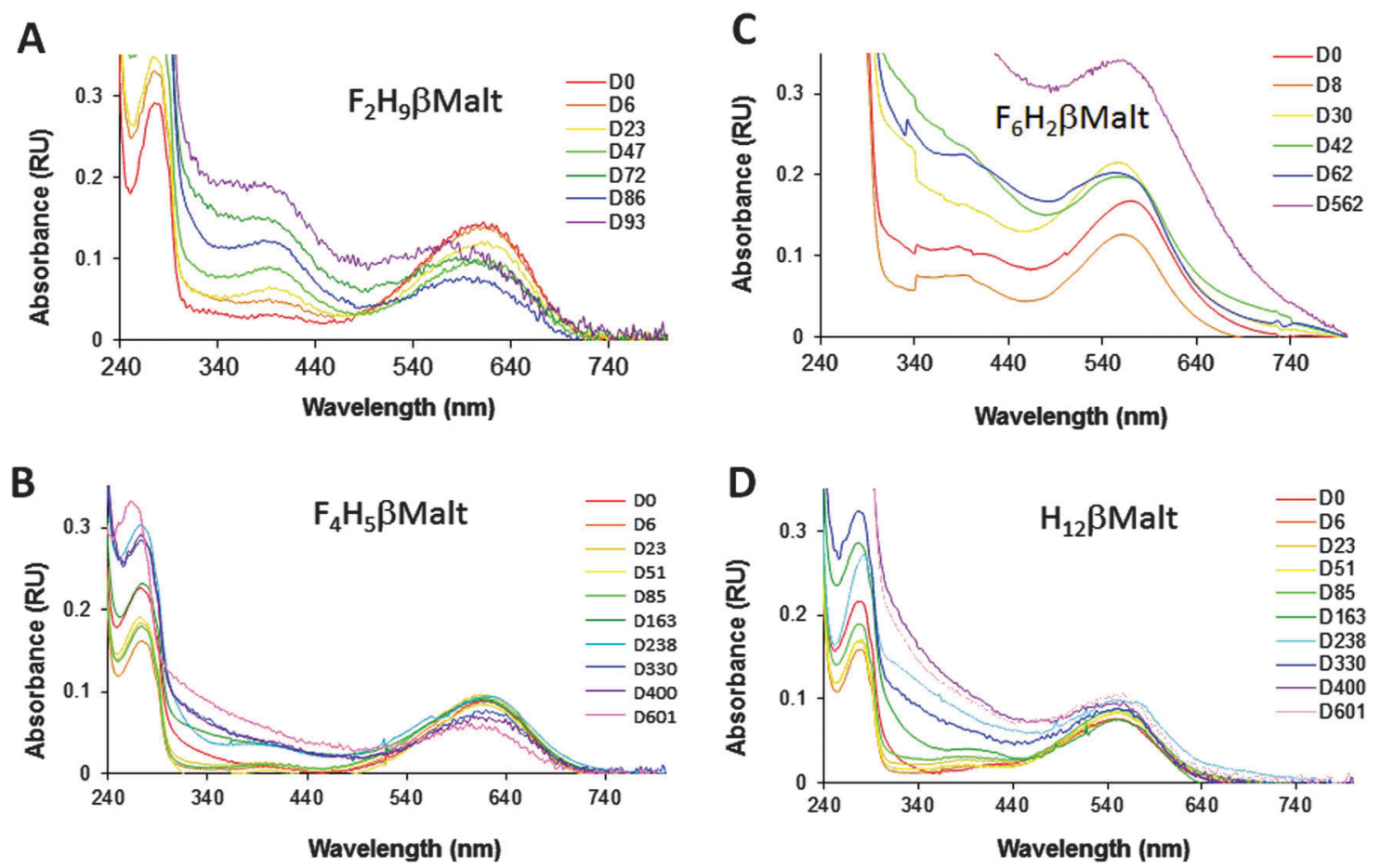

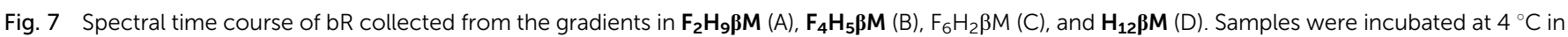
the dark and UV-visible spectra were recorded at the indicated time (given in days, D). 
After a year, the $615 \mathrm{~nm}$ peak looses intensity, without the appearance of a peak at $400 \mathrm{~nm}$ and thus suggests either some bleaching of the $615 \mathrm{~nm} \mathbf{F}_{\mathbf{4}} \mathbf{H}_{\mathbf{5}} \mathbf{\beta} \mathbf{M}$-bR species, or its denaturation or bleaching of the $400 \mathrm{~nm}$ species.

In summary, we conclude that bR is stable as a homogeneous monomer over approximately a month in $\mathbf{F}_{2} \mathbf{H}_{\mathbf{9}} \mathbf{\beta} \mathbf{M}$ but for more than a year in $\mathbf{F}_{\mathbf{4}} \mathbf{H}_{\mathbf{5}} \mathbf{\beta} \mathbf{M}$. By contrast, when transferred into $\mathrm{F}_{6} \mathrm{H}_{2} \beta \mathrm{M}$, bR forms large protein-surfactant complexes, as might be expected from the large micelles formed by that surfactant, ${ }^{20}$ and as already observed for $\mathrm{F}_{6} \mathrm{H}_{3} \beta \mathrm{M} .{ }^{22}$

\section{Conclusions}

We have synthesized and characterized two novel fluorinated maltose-based surfactants having the same theoretical hydrophobicity as the common detergent dodecyl maltoside but bearing a sparingly fluorinated chain. Physicochemical analysis revealed the atypical properties of these fluorinated compounds as compared with their more extensively fluorinated counterparts. Most notably, the hydrophobicity of a fluorinated carbon in a short segment appears to be much lower than predicted by the $1 \mathrm{CF}_{2} \approx 1.5 \mathrm{CH}_{2}$ rule, being even negative in the case of a very short fluorinated segment (i.e., perfluoroethyl tip). Biochemical analysis underlined the great potential of tailoring sparingly fluorinated surfactants for membrane-protein applications, as indicated by their differential ability to stabilize the model protein bacteriorhodopsin over extended periods of time. Bacteriorhodopsin is stable in the monomer state over more than a year in $\mathbf{F}_{\mathbf{4}} \mathbf{H}_{\mathbf{5}} \boldsymbol{\beta} \mathbf{M}$. Future work will focus on expanding such systematic correlations between physicochemical surfactant properties and their suitability for biochemical applications to enable a more rational design of fluorinated surfactants for membrane-protein research.

\section{Acknowledgements}

This work used the platforms of the Grenoble Instruct centre (ISBG; UMS 3518 CNRS-CEA-UJF-EMBL) with support from FRISBI (ANR-10-INSB-05-02) and GRAL (ANR-10-LABX-49-01) within the Grenoble Partnership for Structural Biology (PSB). This study was supported by a PhD grant from the region PACA (Provence Alpes Côte d'Azur-France) via European Regional Development funds (FEDER). We are grateful to the European Synchrotron Radiation Facility for the provision of synchrotron radiation facilities Petra Pernot and Adam Round for assistance in using beamlines ID14-eh3 and BM29.

\section{References}

1 M. A. Yildirim, K. I. Goh, M. E. Cusick, A. L. Barabasi and M. Vidal, Nat. Biotechnol., 2007, 25, 1119.

2 L. Bamber, M. Harding, P. J. G. Butler and E. R. S. Kunji, Proc. Natl. Acad. Sci. U. S. A., 2006, 103, 16224.

3 E. Pebay-Peyroula, R. Garavito, J. Rosenbusch, M. Zulauf and P. Timmins, Structure, 1995, 3, 1051.
4 S. Penel, E. Pebay-Peyroula, J. Rosenbusch, G. Rummel, T. Schirmer and P. A. Timmins, Biochimie, 1998, 80, 543.

5 E. R. Kunji, M. Harding, P. J. Butler and P. Akamine, Methods, 2008, 46, 62.

6 K. H. Park, C. Berrier, F. Lebaupain, B. Pucci, J. L. Popot, A. Ghazi and F. Zito, Biochem. J., 2007, 403, 183.

7 K.-H. Park, E. Billon-Denis, T. Dahmane, F. Lebaupain, B. Pucci, C. Breyton and F. Zito, New Biotechnol., 2007, 28, 255.

8 C. Duval-Terrié, P. Cosette, G. Molle, G. Muller and E. Dé, Protein Sci., 2003, 12, 681.

9 S. M. Yu, D. T. McQuade, M. A. Quinn, C. P. R. Hackenberger, M. P. Krebs, A. S. Polans and S. H. Gellman, Protein Sci., 2000, 9, 2518.

10 J. M. Dörr, M. C. Koorengevel, M. Schäfer, A. V. Prokofyev, S. Scheidelaar, E. A. W. van der Cruijsen, T. R. Dafforn, M. Baldus and J. A. Killian, Proc. Natl. Acad. Sci. U. S. A., 2014, 111, 18607.

11 J. Hovers, M. Potschies, A. Polidori, B. Pucci, S. Raynal, F. Bonneté, M. Serrano-Vega, C. Tate, D. Picot, Y. Pierre, J.-L. Popot, R. Nehmé, M. Bidet, I. Mus-Veteau, H. Bußkamp, K.-H. Jung, A. Marx, P. A. Timmins and W. Welte, Mol. Membr. Biol., 2011, 28, 171.

12 L.-A. Barret, C. Barrot-Ivolot, S. Raynal, C. Jungas, A. Polidori and F. Bonneté, J. Phys. Chem., 2013, B117, 8770.

13 M. Abla, S. Unger, S. Keller, F. Bonnete, C. Ebel, B. Pucci, C. Breyton and G. Durand, J. Colloid Interface Sci., 2015, 445, 127.

14 P. Bazzacco, K. S. Sharma, G. Durand, F. Giusti, C. Ebel, J.-L. Popot and B. Pucci, Biomacromolecules, 2009, 10, 3317.

15 C. Breyton, E. Chabaud, Y. Chaudier, B. Pucci and J.-L. Popot, FEBS Lett., 2004, 564, 312.

16 O. Joubert, R. Nehmé, D. Fleury, M. De Rivoyre, M. Bidet, A. Polidori, M. Ruat, B. Pucci, P. Mollat and I. Mus-Veteau, Biochim. Biophys. Acta, 2009, 1788, 1813.

17 K. H. Park, C. Berrier, F. Lebaupain, B. Pucci, J. L. Popot, A. Ghazi and F. Zito, Biochem. J., 2007, 403, 183.

18 J.-C. Talbot, A. Dautant, A. Polidori, B. Pucci, T. CohenBouhacina, A. Maali, B. n. d. Salin, D. Brèthes, J. Velours and M.-F. Giraud, J. Bioenerg. Biomembr., 2009, 41, 349.

19 P. Barthélémy, V. Tomao, J. Selb, Y. Chaudier and B. Pucci, Langmuir, 2002, 18, 2557.

20 E. Frotscher, B. Danielczak, C. Vargas, A. Meister, G. Durand and S. Keller, Angew. Chem., Int. Ed., 2015, 54, 5069.

21 C. Breyton, B. Pucci and J.-L. Popot, Methods Mol. Biol., 2010, 601, 219.

22 A. Polidori, M. Presset, F. Lebaupain, B. Ameduri, J. L. Popot, C. Breyton and B. Pucci, Bioorg. Med. Chem. Lett., 2006, 16, 5827.

23 J. N. Israelachvili, D. J. Mitchell and B. W. Ninham, Biochim. Biophys. Acta, Biomembr., 1977, 470, 185.

24 V. Vill, T. Böcker, J. Thiem and F. Fischer, Liq. Cryst., 1989, 6, 349. 25 M. J. Rosen, A. W. Cohen, M. Dahanayake and X. Y. Hua, J. Phys. Chem., 1982, 86, 541.

26 S. Keller, C. Vargas, H. Zhao, G. Piszczek, C. A. Brautigam and P. Schuck, Anal. Chem., 2012, 84, 5066.

27 J. Broecker and S. Keller, Langmuir, 2013, 29, 8502.

28 P. Schuck, Biophys. J., 2000, 78, 1606. 
29 H. Zhao, R. Ghirlando, G. Piszczek, U. Curth, C. A. Brautigam and P. Schuck, Anal. Biochem., 2013, 437, 104.

30 C. Breyton, F. Gabel, M. Abla, Y. Pierre, F. Lebaupain, G. Durand, J. L. Popot, C. Ebel and B. Pucci, Biophys. J., 2009, 97, 1077.

31 A. Solovyova, P. Schuck, L. Costenaro and C. Ebel, Biophys. J., 2001, 81, 1868.

32 M. Dahani, L.-A. Barret, P. Loll, C. Jungas, A. Polidori and F. Bonneté, Acta Crystallogr., Sect. F: Struct. Biol. Commun., 2015, 71, 838.

33 H. Durchschlag and P. Zipper, Jorn. Com. Esp. Deterg., Comun., 1995, 29, 275.

34 S. Li, D. Xing and J. Li, J. Biol. Phys., 2004, 30, 313.

35 P. Pernot, A. Round, R. Barrett, A. De Maria Antolinos, A. Gobbo, E. Gordon, J. Huet, J. Kieffer, M. Lentini, M. Mattenet, C. Morawe, C. Mueller-Dieckmann, S. Ohlsson, W. Schmid, J. Surr, P. Theveneau, L. Zerrad and S. McSweeney, J. Synchrotron Radiat., 2013, 20, 660.

36 D. Orthaber, A. Bergmann and O. Glatter, J. Appl. Crystallogr., 2000, 33, 218.

37 K. Shinoda, M. Hato and T. Hayashi, J. Phys. Chem., 1972, 76, 909.

38 J. C. Ravey, A. Gherbi and M. J. Stébé, in Trends in Colloid and Interface Science, ed. V. Degiorgio, Steinkopff, 1988, ch. 40, vol. 76, p. 234.

39 N. Requirand, H. Blancou and A. Commeyras, Bull. Soc. Chim. Fr., 1993, 130, 798.

40 S. Hanessian and J. Banoub, Carbohydr. Res., 1977, 59, 261.

41 J. Dahmén, T. Frejd, G. Grönberg, T. Lave, G. Magnusson and G. Noori, Carbohydr. Res., 1983, 116, 303.

42 G. Milkereit, S. Gerber, K. Brandenburg, M. Morr and V. Vill, Chem. Phys. Lipids, 2005, 135, 1.

43 T. Ogawa, K. Beppu and S. Nakabayashi, Carbohydr. Res., 1981, 93, C6.

44 P. Mukerjee, J. Am. Oil Chem. Soc., 1982, 59, 573.

45 M. J. Rosen, Surfactants and Interfacial Phenomena, New York, 2nd edn, 1989.
46 M. S. Borse and S. Devi, Adv. Colloid Interface Sci., 2006, 123-126, 387.

47 M. J. Rosen and J. T. Kunjappu, Surfactants and interfacial phenomena, New Jersey, 2012.

48 V. M. Sadtler, F. Giulieri, M. P. Krafft and J. G. Riess, Chem. - Eur. J., 1998, 4, 1952.

49 N. Muller and R. H. Birkhahn, J. Phys. Chem., 1967, 71, 957.

50 W. Guo, T. A. Brown and B. M. Fung, J. Phys. Chem., 1991, 95, 1829.

51 S. Dong, X. Li, G. Xu and H. Hoffmann, J. Phys. Chem. B, 2007, 111, 5903.

52 D. P. Bossev, M. Matsumoto and M. Nakahara, J. Phys. Chem. B, 1999, 103, 8251.

53 N. Li, S. Zhang, L. Zheng and T. Inoue, Langmuir, 2009, 25, 10473.

54 P. Long, J. Chen, D. Wang, Z. Hu, X. Gao, Z. Li and J. Hao, J. Phys. Chem. B, 2012, 116, 7669.

55 B. W. Berger, C. M. Gendron, C. R. Rlobinson, E. W. Kaler and A. M. Lenhoff, Acta Crystallogr., Sect. D: Biol. Crystallogr., 2005, 61, 724.

56 S. Finet, D. Vivares, F. Bonneté and A. Tardieu, Macromolecular Crystallography, Pt C, 2003, vol. 368, p. 105.

57 P. Loll, C. Hitscherich, V. Aseyev, M. Allaman and J. Wiencek, Cryst. Growth Des., 2002, 2, 533.

58 O. D. Velev, E. W. Kaler and A. M. Lenhoff, Biophys. J., 1998, 75, 2682.

59 A. Meyer, K. Dierks, R. Hussein, K. Brillet, H. Brognaro and C. Betzel, Acta Crystallogr., Sect. F: Struct. Biol. Commun., 2015, 71, 75 .

60 R. C. Oliver, J. Lipfert, D. A. Fox, R. H. Lo, S. Doniach and L. Columbus, PLoS One, 2013, 8, e62488.

$61 \mathrm{~J}$. Kohlbrecher, SASfit ver. 0.93.3, available at http://kur.web. psi.ch/sans1/SANSSoft/sasfit.html.

62 E. Pebay-Peyroula, G. Rummel, J. P. Rosenbusch and E. M. Landau, Science, 1997, 277, 1676.

63 J. Wang, S. Link, C. D. Heyes and M. A. El-Sayed, Biophys. J., 2002, 83, 1557. 